\title{
Is Curcumin the Answer to Future Chemotherapy Cocktail?
}

\author{
Wei-Yang Kong ${ }^{1}\left(\mathbb{D}\right.$, Siew Ching Ngai ${ }^{1}$, Bey-Hing Goh ${ }^{2,3} \mathbb{D}^{\text {, }}$, Learn-Han Lee ${ }^{4}\left(\mathbb{D}\right.$, Thet-Thet Htar ${ }^{2} \mathbb{D}$ and \\ Lay-Hong Chuah ${ }^{2, *(D)}$
}

1 School of Biosciences, Faculty of Science and Engineering, University of Nottingham Malaysia, Semenyih 43500, Selangor, Malaysia; leonkong93@gmail.com (W.-Y.K.); eunice.ngai@nottingham.edu.my (S.C.N.)

2 Biofunctional Molecule Exploratory Research Group, School of Pharmacy, Monash University Malaysia, Bandar Sunway 47500, Selangor, Malaysia; goh.bey.hing@monash.edu (B.-H.G.); thet.thet.htar@monash.edu (T.-T.H.)

3 College of Pharmaceutical Sciences, Zhejiang University, 866 Yuhangtang Road, Hangzhou 310058, China

4 Novel Bacteria and Drug Discovery (NBDD) Research Group, Microbiome and Bioresource Research Strength, Jeffrey Cheah School of Medicine and Health Sciences, Monash University Malaysia, Bandar Sunway 47500, Selangor, Malaysia; lee.learn.han@monash.edu

* Correspondence: alice.chuah@monash.edu; Tel.: +60-355144454

Citation: Kong, W.-Y.; Ngai, S.C.; Goh, B.-H.; Lee, L.-H.; Htar, T.-T.; Chuah, L.-H. Is Curcumin the Answer to Future Chemotherapy Cocktail?. Molecules 2021, 26, 4329. https://doi.org/10.3390/molecules 26144329

Academic Editor: Chiara Porro

Received: 16 June 2021

Accepted: 12 July 2021

Published: 17 July 2021

Publisher's Note: MDPI stays neutral with regard to jurisdictional claims in published maps and institutional affiliations.

Copyright: (C) 2021 by the authors. Licensee MDPI, Basel, Switzerland. This article is an open access article distributed under the terms and conditions of the Creative Commons Attribution (CC BY) license (https:// creativecommons.org/licenses/by/ $4.0 /)$.

\begin{abstract}
The rise in cancer cases in recent years is an alarming situation worldwide. Despite the tremendous research and invention of new cancer therapies, the clinical outcomes are not always reassuring. Cancer cells could develop several evasive mechanisms for their survivability and render therapeutic failure. The continuous use of conventional cancer therapies leads to chemoresistance, and a higher dose of treatment results in even greater toxicities among cancer patients. Therefore, the search for an alternative treatment modality is crucial to break this viscous cycle. This paper explores the suitability of curcumin combination treatment with other cancer therapies to curb cancer growth. We provide a critical insight to the mechanisms of action of curcumin, its role in combination therapy in various cancers, along with the molecular targets involved. Curcumin combination treatments were found to enhance anticancer effects, mediated by the multitargeting of several signalling pathways by curcumin and the co-administered cancer therapies. The preclinical and clinical evidence in curcumin combination therapy is critically analysed, and the future research direction of curcumin combination therapy is discussed.
\end{abstract}

Keywords: cancer; curcumin; combination therapy; chemotherapy cocktail; signalling pathways; anticancer

\section{Introduction}

Cancer has remained a serious threat to public health worldwide for centuries, and its prevalence is multiplying at a worrying rate. According to global cancer statistics (GLOBOCAN) 2020, there will be about a 47\% increase in cancer incidence in 2040 as compared to the estimated cases in 2020. The growing burden of cancer cases will likely correspond to the mortality rate among cancer patients, especially breast cancer and colorectal cancer [1]. With continuous collaborative research efforts between scientists and clinicians, multiple treatment modalities have been developed and improved throughout the years to control cancer aggravation, for instance, surgery, chemotherapy, radiotherapy and immunotherapy [2]. Fortunately, these treatment interventions have led to a decline in the mortality rate for cancer patients. However, not all cancer patients benefit completely from these treatments, owing to the difference in susceptibility to cancer treatment, heterogeneity of cancer, therapeutic resistance development and unprecedented side effects [3]. Hence, more initiatives are needed in the quest for more potent treatment modalities for a wide range of cancer patients to overcome the therapeutic obstacles.

Over the years, the concept of combination therapy, which relies on two or more therapeutic agents, has been introduced in the development of cancer treatment [4]. Compared 
to conventional single-agent therapies, combination therapy exhibits numerous benefits, such as targeting multiple oncogenic pathways, reducing high toxicity levels implicated by monotherapy, improving the magnitude of therapeutic responses and reducing the likelihood of therapeutic resistance [5]. These benefits allow for the greater suppression of cancer cells and reduce the risk of cancer recurrence, thus improving the patient's quality of life $[4,6]$. Lately, curcumin has gained a great deal of interest, attributed to its broad range of medicinal properties [7]. Intriguingly, curcumin exhibited countless anticancer properties, such as limiting cancer cell proliferation, promoting tumor cell death and preventing metastasis $[7,8]$. Besides, curcumin supplementation greatly relieves the patients from experiencing adverse effects caused by conventional therapies [6]. Hence, these properties pose great advantages to the development of curcumin combination therapy for cancer treatment.

This review focuses on the use of curcumin in combination therapy in various cancers. The evasive mechanisms developed by cancer cells in response to cancer therapy are discussed. Curcumin combination therapies used are reviewed in depth in each type of cancer in both preclinical and clinical studies. We also addressed how curcumin modulates a variety of molecular targets in cancer cells in the combination treatment, to provide an insight into the multitargeting effects of such treatment cocktails.

\section{Evasive Mechanisms and Chemoresistance}

Though the development of cancer therapy has achieved progressive milestones from conventional chemotherapeutic agents to the more advanced monoclonal antibodies and immunotherapy, inconsistencies and irresponsiveness towards the therapies were observed among the cancer patients receiving various cancer treatments, resulting in mixed outcomes among patients. Owing to the neoplastic characteristics, cancer cells are continuously evolving and adapting to the stress response induced by cancer therapies, developing numerous evasive mechanisms pertaining to the hallmark of cancer as their defensive strategies against chemotherapy [9]. Figure 1 summarizes the different evasive mechanisms by cancer cells.

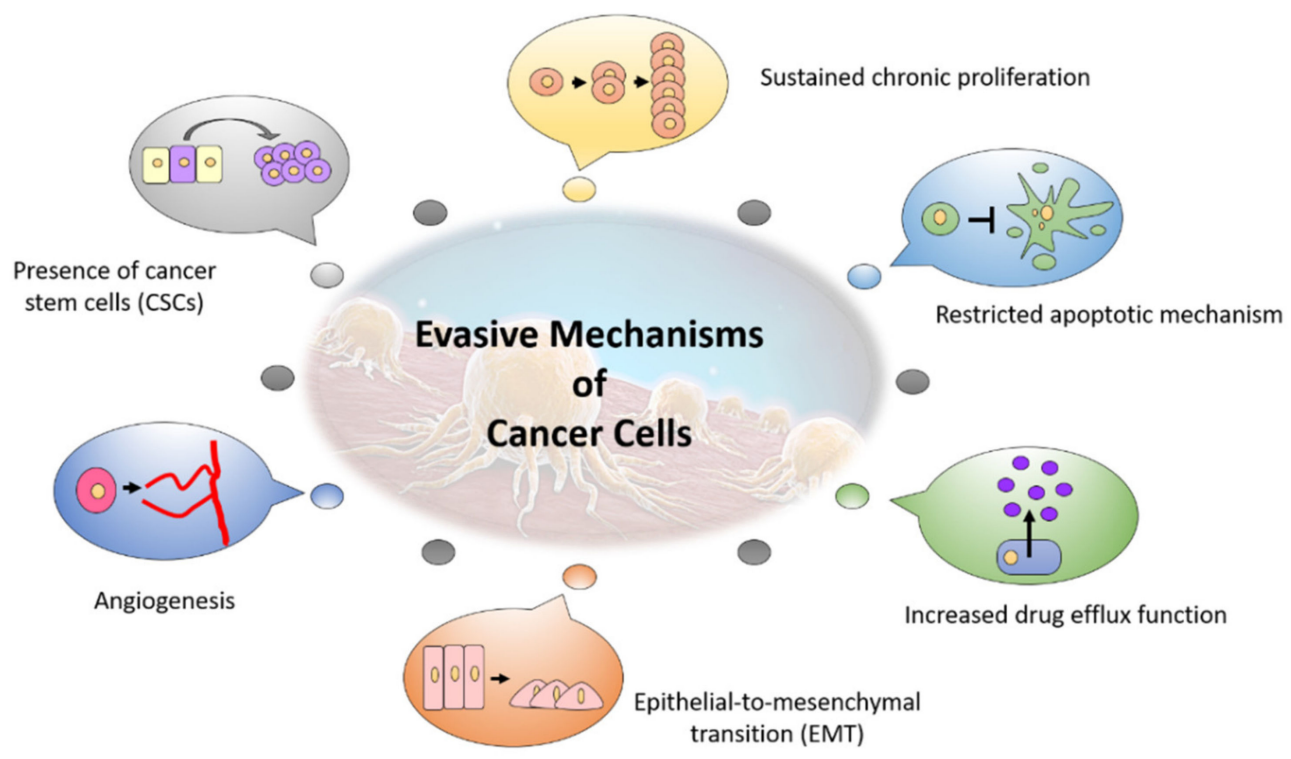

Figure 1. The evasive mechanisms developed by cancer cells in response to cancer therapy. 


\subsection{Sustained Chronic Proliferation}

Cancer is notorious for the sustained chronic proliferation behaviour in the body [9]. It is capable of neutralizing the cytotoxicity effects by profoundly accelerating cell proliferation to promote survival benefits. This uncontrolled cell growth is greatly manifested by the constitutive activation of several proliferation-related signalling pathways, notably transforming growth factor- $\beta$ (TGF- $\beta$ ), phosphoinositide 3-kinase(PI3K)/protein kinase $\mathrm{B}(\mathrm{Akt}) /$ mechanistic target of rapamycin (mTOR), epidermal growth factor receptor (EGFR), mitogen-activated protein kinase (MAPK) and nuclear factor $k$-light-chain-enhancer of activated B cells (NF-KB) pathways in cancer cells $[3,10]$. Additionally, cancer cells induce aberrant cell growth through the dysregulation of the cell cycle and modulation of cell cycle-related proteins. Evading the cancer therapy, cancer cells usually instigate high activities of cyclin-dependent kinase (CDK), with the abnormal amplification of cyclin D, to accelerate the cancer cell proliferation [11,12]. Concurrently, the uncontrolled cell cycle progression is tightly associated with the decreased expression or loss of function of CDK inhibitors such as p21 and p27 [13]. Apart from its intrinsic mutation in cancer cells, tumor suppressor protein p53 is frequently downregulated in response to cancer therapy, thereby abolishing its anti-proliferative, anti-apoptosis and anti-metastatic activities [14].

\subsection{Restricted Apoptotic Mechanism}

Restricting the apoptotic mechanism is another strategy of cancer cells to override the killing effects induced by conventional therapies. As an orchestrated event in regulating physiological function, apoptosis mainly involves the extrinsic death receptor (DR) pathway and intrinsic mitochondrial pathway, which are tightly regulated by the balance of apoptotic proteins [15]. To maintain its immortality and metastatic behaviours, cancer cells have established several mechanisms to avoid apoptosis induction by cancer therapies [16]. As extensively reviewed in the literature, the fate of cell death is modulated by the balance of B-cell lymphoma 2 (Bcl-2) family proteins, which are composed of pro-apoptotic proteins, such as Bcl-2 homology 3 (BH3)-interacting domain death agonist (Bid), BH3-only Bcl-2interacting mediator of cell death (Bim), Bcl-2-associated X protein (Bax), Bcl-2 homologous antagonist/killer (Bak) and Bcl-2-interacting killer (Bik), and anti-apoptotic proteins, such as Bcl-2, B-cell lymphoma-extra-large (Bcl-xL), induced myeloid leukemia cell differentiation protein (Mcl-1), and Bcl-2-like protein 10 (Bcl2L10) [17]. The ratio of Bax/Bcl-2 is sometimes applied as the prognostic marker and susceptibility of a particular cancer treatment to cancer patients $[18,19]$. The overexpression of Bcl-2 is highly correlated with poor therapeutic efficacy among cancer patients [20]. Besides, the inhibitor of apoptosis (IAP) protein families, including cellular inhibitor of apoptosis protein 1 (cIAP1), cellular inhibitor of apoptosis protein 2 (cIAP2), X-linked inhibitor of apoptosis protein (XIAP) and survivin, are important determinants in the restriction of cancer cell death. These IAPs bind to the active site of caspases, thus limiting caspase activation and apoptosis induction [16]. Furthermore, the impairment of the extrinsic DR pathway was demonstrated by cancer cells to evade the apoptosis induced by chemotherapies. Apart from the downregulation of DRs, the reduced surface expression of DRs due to endocytosis was initiated by cancer cells, limiting the sensitivity of cancer cells towards drug treatments [21,22].

\subsection{Increased Drug Efflux Function}

The drug efflux mechanism is increased in cancer cells as a means to escape drug cytotoxicity effects [23]. The drug efflux function is governed by multidrug resistance protein (MDR), which belongs to the ATP binding cassette (ABC) transport families, notably P-glycoprotein (P-gp) (also known as multidrug resistance protein 1 (MDR1)), multidrug resistance-associated protein 1 (MRP1) and breast cancer resistance protein (BCRP) [24]. The overexpression of MDRs is found in a considerable number of cancers with both intrinsic and acquired resistance [25]. Furthermore, the upregulated expression of oncogenic kinases, such as MAPK and extracellular-signal-regulated kinase (ERK) signalling, caused the elevation of MDR expression in cancer cells, thus limiting the drug sensitivity. Apart 
from preventing the accumulation of chemotherapeutic drugs, these MDRs influence the pharmacokinetics, such as drug biodistribution, drug metabolism and toxicity, on the drug treatment $[26,27]$. Albeit many MDR-targeting therapeutics were developed to circumvent the chemoresistance issue, but the clinical benefits were not well justified due to high toxicity and underreporting of MDR protein inhibition in patient samples [24].

\subsection{Epithelial to Mesenchymal Transition}

Characterized by the dissolution of adherens junctions and loss of cell-cell contacts, the Epithelial to mesenchymal transition (EMT) process is tightly modulated by TGF- $\beta$ /Smad signalling, which directs the downstream regulation of Snail, zinc finger E-box-binding homeobox (ZEB) and basic helix-loop-helix (bHLH) transcription factor families [28,29]. Concomitantly, this causes the loss of epithelial markers E-cadherin, while acquiring the mesenchymal features through upregulation of $\mathrm{N}$-cadherin and vimentin [30]. In addition to that, EMT potentiates the migration and invasive behaviours of cancer cells to other parts of tissues. The expression level of the aforementioned biomarkers is important in determining the sensitivity of chemotherapeutic drug treatments in cancer cells $[9,28]$. The elevation of E-cadherin expression restored the sensitivity to tyrosine kinase inhibitors (TKIs) in lung cancer stem cells (CSCs) [31]. Furthermore, it has been shown that patients with mesenchymal-like urothelial cancer cells had the worst prognosis as compared to patients with epithelial luminal tumors [32]. These studies suggest that the emergence of EMT in cancer cells are prone to defence against chemotherapeutic drugs.

\subsection{Angiogenesis}

Angiogenesis also plays a major role in the chemoresistance capability of cancer cells. During metastasis, angiogenesis was initiated to sustain its nutrients and oxygen supplies for cancer cells $[9,28]$. This phenomenon is modulated by an unbalanced mix of multifaceted angiogenic regulators, including the aberrant amplification of vascular endothelial growth factor (VEGF) and the dysregulation of matrix metalloproteinase (MMP) activities, thus enabling the matrix remodelling, metastasis of cancer cells to other tissues, and microvessel formation [33]. Furthermore, in order to survive in an oxygen-deprived condition, cancer cells had augmented the expression of hypoxia-inducible factor 1- $\alpha$ (HIF-1 $\alpha$ ) which could, in turn, stimulate pro-angiogenic activities [34]. The upregulation of pro-angiogenic activities has promoted therapeutic resistance by hindering cell death, preparing for a pro-survival mechanism and directing metastasis in tumor cells [35].

\subsection{Cancer Stem Cells (CSCs)}

Being self-renewable with differentiation potency, CSCs have been recognized as the crucial factor in rendering cancer treatment failure [36]. Despite the bulk elimination of tumor cells by chemotherapy, this small population of CSCs within the tumor cell pool exhibits their unlimited proliferative and survival capacities to establish more powerful metastatic and invasive characteristics, causing cancer to relapse [3]. Furthermore, CSCs survive the stress of chemotherapy by developing several resistance mechanisms, notably the inhibition of apoptosis, protection against oxidative DNA damage and induction of EMT [37]. Drug accumulation in CSCs was also countered by the enhanced expression of MDR, thereby limiting the drug cytotoxicity effects $[23,38]$. Besides, CSCs cause the massive upregulation of numerous oncogenic signalling pathways, such as Wnt/ $\beta$-catenin, Notch, $\mathrm{PI} 3 \mathrm{~K} / \mathrm{Akt} / \mathrm{mTOR}$ signalling pathways, in order to sustain its proliferative, metastatic and chemoresistance potential, thereby overriding the chemotherapeutic drug effects [36]. As CSCs reside within a tumor niche, the interaction with cancer-associated fibroblasts and tumor-associated macrophages promotes the secretion of numerous cytokines, transcription factors and growth factors within the tumor microenvironment, triggering CSCs to become more resistant to cancer treatment [39]. 


\section{Curcumin and Its Medicinal Properties}

Curcumin, also regarded as diferuloylmethane, is a yellow polyphenol extracted from the rhizome of the Curcuma longa (turmeric) plant, belonging to the Zingiberaceae family [40]. Indigenous in south-eastern and southern tropical Asia, curcumin is vastly utilized for food preservation, colouring and flavouring in daily activities [41]. Moreover, curcumin is traditionally applied for pain-relieving and wound healing effects. Commercial curcumin products contain approximately $77 \%$ curcumin, $18 \%$ demethoxycurcumin and $5 \%$ bisdemethoxycurcumin [42]. Out of those curcuminoids, curcumin exhibits the most potent medicinal properties as compared to demethoxycurcumin and bisdemethoxycurcumin [41]. A growing body of evidence has demonstrated the benefits of curcumin in treating various diseases, including metabolic syndromes, hyperlipidaemia, inflammatory skin conditions, neurodegeneration and rheumatoid arthritis. These clinical benefits are attributed to the anti-inflammatory, anti-oxidant, and wound healing activities of curcumin $[2,8,40]$. Moreover, curcumin can impede pathogenic infections by exerting a broad spectrum of anti-bacterial, anti-fungal and anti-viral activities [43]. Alongside profound medicinal properties, curcumin is listed as a "generally recognized as safe (GRAS)" compound by the Food and Drug Administration (FDA), supporting its safety and tolerability when consumed by patients [7].

Enormous attention has given to the exploration of anticancer properties in curcumin. To date, curcumin has shown its anticancer benefits in numerous cancers such as breast cancer [44,45], colorectal cancer [46], lung cancer [47], pancreatic cancer [48] and prostate cancer [49]. In fact, these anticancer effects depicted by curcumin are highly associated with the modulation of several oncogenic signalling pathways, which are essential in cancer development. Curcumin constrains these oncogenic signalling pathways and further limits the downstream pro-tumorigenic activities. In vitro studies illustrated that curcumin treatment limited the proliferation and caused cell cycle arrest in HT-29 colon cancer cells and $\mathrm{PLC} / \mathrm{PRF} / 5$ liver cancer cells via the inhibition of cyclin D1, with the downregulation of NF- $\mathrm{kB}$ and cyclooxygenase-2 (COX-2) signalling [50-53]. Concurrent with the upregulation of tumor suppressor gene $\mathrm{p} 53$, curcumin repressed the proliferative potential of cancer cells via the downregulation of PI3K/Akt/mTOR signalling [54-56]. Furthermore, it also impedes cancer cells' survival and suppresses their metastatic ability through the downregulation of EGFR pathways [57,58] and inhibition of MMP activities [59,60]. Apart from limiting the expression of IAP family proteins, curcumin promotes the apoptosis of cancer cells by increasing the expression of Bax while downregulating the expression of Bcl-2 in various cancer cells $[61,62]$. It has also been shown to be able to abrogate angiogenesis elicited by breast tumors via the suppression of VEGF [63]. The anticancer properties elucidated by curcumin are summarized in Figure 2.

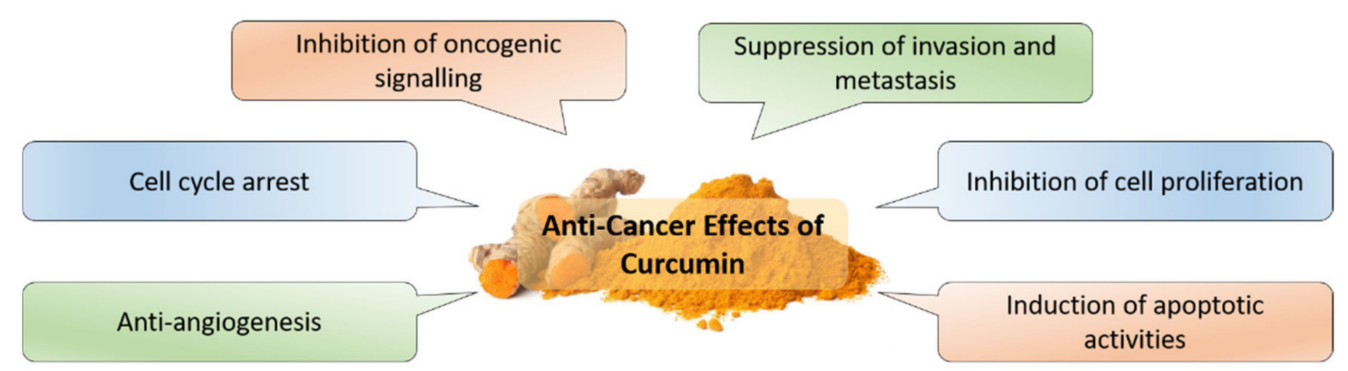

Figure 2. Curcumin elicits various anticancer effects in cancer treatment. 


\section{Curcumin Combination Anticancer Therapy in Preclinical Studies}

Conventional cancer therapies are challenged by the various defence mechanisms developed in cancer cells, hindering treatment success. Moreover, cancer cells often exhibit more than one mechanism of resistance, further complicating the treatment regimen. Hence, multiple targeting of these evasive mechanisms could potentially restore the sensitivity of cancer cells to cancer therapy, apart from eliminating the cancer cells completely. In this regard, curcumin holds a great promise in combination therapy to enhance the anticancer effects, while circumventing the problems encountered in conventional therapies. Since curcumin exhibits pleiotropic effects, the co-administration of curcumin in cancer therapy allows multiple targeting to the cancer-surviving and cancer-limiting mechanisms, while conventional monotherapy is restricted by single mechanism targeting only. Moreover, repetitive monotherapy caused the cancer cells to recruit other salvage pathways for survival benefits [4]. Hence, curcumin combination therapy could offset the evasion of cancer therapy and survivability of cancer cells, thereby overcoming the risk of cancer recurrence and treatment failure. To ensure the complete elimination of cancer cells, conventional monotherapy is often administered at a high dosage and causes a series of unwanted side effects [5]. Moreover, it was well known to be non-selective in killing proliferating cancer cells as well as healthy normal cells, upsetting the body immune system, and resulting in high toxicity [4]. These drawbacks could be alleviated by coadministering curcumin, such that a lower dosage of therapeutic agents is required. Thus, this could reduce the toxicity and adverse effects encountered by patients, besides yielding a significant therapeutic response $[6,64]$. To date, numerous preclinical investigations involving in vitro, in vivo and ex vivo studies have been conducted on the use of curcumin in combination therapy in various cancers (Table 1). 


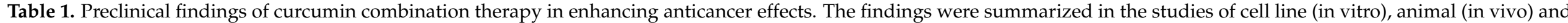
tissues/organs experimentation under more controlled condition (ex vivo).

Main Findings

Chemotherapeutic Drugs

In Vitro

In Vivo/Ex Vivo

References

1. Inhibition of cell proliferation via the repression of Akt/mTOR signalling.

2. Increased apoptotic activities via the activation of pro-apoptotic protein BcL-xL; repression of

Tamoxifen anti-apoptotic protein Bcl-2.

3. Induction of $\mathrm{G} 2 / \mathrm{M}$ arrest via the inhibition of c-Myc

and cyclin D1; downregulation of p21.

4. Reversal of tamoxifen-induced chemoresistance via

the suppression of p65 phosphorylation, EZH2

expression and SLUG/HK2 pathway.

\section{Breast cancer}

Trastuzumab
1. Inhibition of cell proliferation via the repression of NF- $\kappa \mathrm{B}$ and HER2.

2. Induction of $\mathrm{G} 2 / \mathrm{M}$ arrest via the repression of Akt and 1. Inhibition of tumor growth.

MAPK phosphorylation.

3. Reduction in cancer cell migration.

1. Inhibition of cell proliferation via the suppression of COX-2 and c-Myc.

2. Increased apoptotic activities via the activation of pro-apoptotic protein Bax; repression of anti-apoptotic protein Bcl-2; upregulation of caspase 3/8 activity.

Paclitaxel

3. Reduction in cancer cell migration via the suppressio of MMP-9 and ICAM-1.

4. No toxicity to normal cell lines.

5. Reversal of paclitaxel-induced chemoresistance via the upregulation of p53; downregulation of NF-kB, COX-2 and EGFR.
1. Inhibition of tumor growth via the suppression of NF-kB.

2. Prevention of breast cancer metastasis to lung tissues via the downregulation of 
Table 1. Cont.

In Vitro

\section{Main Findings}

In Vitro

In Vivo/Ex Vivo

References

1. Inhibition of cell proliferation via the suppression of

PI3K/Akt, GSK3 $\beta$, $\beta$-catenin phosphorylation.

Doxorubicin

2. Inhibition of efflux function of $A B C B 4$ via the

inhibition of ATPase activities of ABCB4.

3. Inhibition of EMT via the upregulation of E-cadherin;

downregulation of Smad2 phosphorylation.

1. Increase intracellular retention of doxorubicin.

2. Reversal of Pgp-induced chemoresistance via the in solid lipid nanoparticle)

upregulation of p50, p65 and c-Rel expression.
1. Inhibition of tumor growth via

the suppression of $\mathrm{p} 38$

activation.

2. Decreased in weight of tumor

mass.

1. Inhibition of cell proliferation via the suppression of Akt phosphorylation

2. Reversal of HER2-induced chemoresistance via the

downregulation of HER2.

Quercetin, Optiberry, lapatinib

1. Reduced tumor weight and

volume via the

downregulation of EGFR, Akt

and VEGFR-1.

$2 . \quad$ Induction of $\mathrm{G} 2 / \mathrm{M}$ arrest.

2. Co-treatment was non-toxic to

mice.

1. Inhibition of cell proliferation via the activation of ERK pathway.

2. Increased apoptotic activities via the activation of

pro-apoptotic protein Bax; repression of anti-apoptotic protein Bcl-2; upregulation of caspase 3 activity and

3. Induction of autophagic cell death via the

upregulation of JNK signalling. 
Table 1. Cont.

\section{Cancer Type}

Chemotherapeutic Drugs
Colorectal cancer/colon cancer
$5-\mathrm{FU}$

Oxaliplatin

Irinotecan

Inhibition of cell proliferation via the suppression of

Wnt signalling.

2. Increased apoptotic activities via the upregulation of caspase $3 / 8$ activities and PARP cleavage; repression of Bcl-xL.

3. Induction of G0/G1 phase and S phase arrest via the suppression of cyclin D1.

4. Reduction in cancer cell migration and invasiveness via the suppression of MMP-9, CXCR4.

5. Reversal of 5-FU-induced chemoresistance via the suppression of NF- $\mathrm{kB}$ and Pgp.

6. Inhibition of autophagy via the downregulation of AMPK signalling.

1. Inhibition of cell proliferation via the inhibition of TGF- $\beta /$ Smad $2 /$ Smad 3 signalling.

2. Increased apoptotic activities via the upregulation of caspase 3 activity; repression of anti-apoptotic protein Bcl-2.

3. Inhibition of EMT via the downregulation of $\mathrm{N}$-cadherin; upregulation of E-cadherin.

Inhibition of cell proliferation.

2. Increased endoplasmic reticulum stress-induced apoptotic activities via the activation of pro-apoptotic protein Bax; repression of anti-apoptotic protein $\mathrm{Bcl}-2$ suppression of CHOP activity; induction of ROS production; upregulation of caspase $3 / 8$ activity.

Induction of $S$ phase arrest.

4. Reduced spheroid formation of cancer stem cells via the suppression of CD44, CD24 and EpCAM expression.
1. Inhibition of tumor growth.

2. Co-treatment was non-toxic to [77-81] mice.

1. Reduced tumor weight and volume via the suppression of Smad 2 and Smad3 phosphorylation in tumor tissues. 
Table 1. Cont.

\begin{tabular}{|c|c|c|c|c|}
\hline \multirow{2}{*}{ Cancer Type } & \multirow{2}{*}{ Chemotherapeutic Drugs } & \multicolumn{2}{|l|}{ Main Findings } & \multirow{2}{*}{ References } \\
\hline & & In Vitro & In Vivo/Ex Vivo & \\
\hline \multirow{3}{*}{$\begin{array}{l}\text { Colorectal cancer/colon } \\
\text { cancer }\end{array}$} & Dasatinib & $\begin{array}{l}\text { 1. Inhibition of cell proliferation. } \\
\text { 2. Reduced sphere-forming potential. } \\
\text { 3. Reduction in cancer cell invasiveness. } \\
\text { 4. Decreased expression of cancer stem cell markers via } \\
\text { the suppression of ALDH, CD44, CD133 and CD166. }\end{array}$ & $\begin{array}{l}\text { 1. Reduction in the cancer stem } \\
\text { cells markers ALDH, CD44, } \\
\text { CD133 and CD166 in tumor } \\
\text { tissues. }\end{array}$ & [85] \\
\hline & FOLFOX & $\begin{array}{l}\text { 1. Inhibition of cell proliferation via the suppression of } \\
\text { stem cell markers CD166, CD44 and EGFR expression } \\
\text { in FOLFOX-surviving cancer cells. } \\
\text { 2. Increased the methylation status of EGFR. } \\
\text { 3. Suppression of EGFR expression via the upregulation } \\
\text { of DNMT1 and methylation status of EGFR. } \\
\text { 4. Inhibition of colony formation. }\end{array}$ & & [89] \\
\hline & FOLFOX, bevacizumab & & $\begin{array}{l}\text { 1. Inhibition of tumor growth via } \\
\text { the increase in apoptosis in } \\
\text { tumor area. } \\
\text { 2. Co-treatment was non-toxic to } \\
\text { mice. } \\
\text { 3. Reduction in the angiogenesis } \\
\text { effect by reduced expression } \\
\text { of CD31 and Factor VIII in } \\
\text { stained tissues. }\end{array}$ & {$[90]$} \\
\hline
\end{tabular}


Table 1. Cont.

\begin{tabular}{|c|c|c|c|c|c|}
\hline \multirow{2}{*}{ Cancer Type } & \multirow{2}{*}{ Chemotherapeutic Drugs } & \multicolumn{3}{|c|}{ Main Findings } & \multirow{2}{*}{ References } \\
\hline & & & In Vitro & In Vivo/Ex Vivo & \\
\hline \multirow[b]{2}{*}{$\begin{array}{l}\text { Colorectal cancer/colon } \\
\text { cancer }\end{array}$} & Silymarin & $\begin{array}{l}1 . \\
2 .\end{array}$ & $\begin{array}{l}\text { Inhibition of cell proliferation. } \\
\text { Increased apoptotic activities via the upregulation of } \\
\text { caspase } 3 / 7 \text { activities. }\end{array}$ & & [91] \\
\hline & Resveratrol & $\begin{array}{l}1 . \\
2 . \\
3 .\end{array}$ & $\begin{array}{l}\text { Inhibition of cell proliferation via the suppression of } \\
N F-k B \text {, EGFR, HER2, HER3 and IGF-1R. } \\
\text { Increased apoptotic activities. } \\
\text { Induction of } S \text { phase arrest. }\end{array}$ & $\begin{array}{l}\text { 1. Inhibition of tumor growth via } \\
\text { the inhibition of mitotic index } \\
\text { and increased apoptosis in } \\
\text { tumor area. } \\
\text { 2. Co-treatment was non-toxic to } \\
\text { mice. }\end{array}$ & [92] \\
\hline \multirow[t]{2}{*}{ Lung cancer } & Gefitinib & $\begin{array}{l}2 . \\
3 . \\
4 .\end{array}$ & $\begin{array}{l}\text { Inhibition of cell proliferation via the suppression of } \\
\text { Akt and ERK1/2 phosphorylation; induction of } \\
\text { proteasomal-induced degradation of EGFR protein; } \\
\text { inhibition of EGFR pathway. } \\
\text { Increased apoptotic activities via the upregulation of } \\
\text { caspase } 3 \text { activity and PARP cleavage; repression of } \\
\text { anti-apoptotic protein survivin. } \\
\text { Induction of autophagy-related cell death via the } \\
\text { increase in LC3-II. } \\
\text { Harmless to intestinal epithelial cell line. }\end{array}$ & $\begin{array}{l}\text { 1. Inhibition of tumor growth. } \\
\text { 2. Reduction in tumor volume } \\
\text { via the downregulation of } \\
\text { Sp1/EGFR signalling. } \\
\text { 3. Attenuation of adverse } \\
\text { gastrointestinal effects } \\
\text { induced by gefitinib. }\end{array}$ & [93-95] \\
\hline & Erlotinib & 1. & $\begin{array}{l}\text { Inhibition of cell proliferation via the downregulation } \\
\text { of NF- } \kappa B \text { and EGFR; upregulation of I } \kappa B \text { expression. } \\
\text { Increased apoptotic activities via the upregulation of } \\
\text { caspase } 3 / 9 \text { cleavage; repression of anti-apoptotic } \\
\text { protein survivin. }\end{array}$ & $\begin{array}{l}\text { 1. Inhibition of tumor growth via } \\
\text { the upregulation of IкB; } \\
\text { downregulation of NF- } \mathrm{kB} \text {. } \\
\text { 2. Reduction in tumor weight. } \\
\text { 3. No metastases were observed } \\
\text { in tissues. }\end{array}$ & {$[96,97]$} \\
\hline
\end{tabular}


Table 1. Cont

\section{Cancer Type}

Chemotherapeutic Drugs

Cisplatin

Cisplatin, radiotherapy

Carboplatin
Lung cancer

\section{In Vitro}

\section{Main Findings}

1. Inhibition of cell proliferation via the downregulation of cyclin D1, Akt/mTOR pathway; upregulation of p21.

2. Increased apoptotic activities via the activation of pro-apoptotic protein Apaf-1; repression of anti-apoptotic protein Bcl-2; upregulation of caspase $3 / 9$ activity.

3. Inhibition of cancer cell migration.

4. Reversal of cisplatin-induced chemoresistance via the downregulation of FANCD2 monoubiquitination, ERCC1-related signalling pathways, CA916798 expression and HIF- $1 \alpha$ expression through ubiquitin-proteasome degradation.
1. Inhibition of tumor growth.

2. Reduction in tumor volume.
References

In Vivo/Ex Vivo

1. Inhibition of cell proliferation via the suppression of EGFR expression.

2. Inhibition of cancer cell migration and invasiveness

3. Sensitization to radiotherapy treatment via the suppression of EGFR expression.

1. Inhibition of cell proliferation via the upregulation of p21 and ERK1/2 phosphorylation; downregulation of NF-KB expression and Akt phosphorylation.

2. Increased apoptotic activities via the activation of pro-apoptotic proteins Bax and p53; suppression of anti-apoptotic protein Bcl-2.

3. Inhibition of cancer cell migration and invasiveness via the downregulation of MMP-2/9 activity. 
Table 1. Cont.

\begin{tabular}{|c|c|c|c|c|c|}
\hline \multirow{2}{*}{ Cancer Type } & \multirow{2}{*}{ Chemotherapeutic Drugs } & \multicolumn{3}{|c|}{ Main Findings } & \multirow{2}{*}{ References } \\
\hline & & & In Vitro & In Vivo/Ex Vivo & \\
\hline \multirow{4}{*}{ Lung cancer } & Paclitaxel & $\begin{array}{l}1 \\
2\end{array}$ & $\begin{array}{l}\text { Inhibition of cell proliferation. } \\
\text { Reversal of paclitaxel-induced chemoresistance via the } \\
\text { downregulation of miR-30c-5p-directed MTA1 mRNA. }\end{array}$ & & [105] \\
\hline & $\begin{array}{l}\text { Paclitaxel (with curcumin } \\
\text { encapsulated in PCDT) }\end{array}$ & $\begin{array}{l}1 \\
2 \\
3\end{array}$ & $\begin{array}{l}\text { Inhibition of cell proliferation. } \\
\text { Inhibition of clonogenic formation. } \\
\text { Increased apoptotic activities. }\end{array}$ & & [106] \\
\hline & $\begin{array}{l}\text { Doxorubicin (with curcumin loaded } \\
\text { with micelles) }\end{array}$ & $\begin{array}{l}2 \\
3\end{array}$ & $\begin{array}{l}\text { Maintained distinctive biodistribution profile of } \\
\text { doxorubicin. } \\
\text { Micelle system remained stable for } 24 \mathrm{~h} \text {. } \\
\text { Harmless to normal cell line. }\end{array}$ & $\begin{array}{l}\text { 1. Inhibition of tumor growth. } \\
\text { 2. Reduction in cardiotoxicity } \\
\text { effect induced by doxorubicin } \\
\text { via the downregulation of } \\
\text { SOD and GSH-Px. } \\
\text { 3. Body tissues were protected } \\
\text { from oxidative stress. }\end{array}$ & [107] \\
\hline & $\begin{array}{l}\text { Doxorubicin (with curcumin } \\
\text { encapsulated in U-11 targeting } \\
\text { nanoparticle) }\end{array}$ & & $\begin{array}{l}\text { Inhibition of cell proliferation. } \\
\text { Increased cellular uptake of doxorubicin and } \\
\text { curcumin. }\end{array}$ & 1. Inhibition of tumor growth. & [109] \\
\hline
\end{tabular}


Table 1. Cont.

\begin{tabular}{|c|c|c|c|c|c|}
\hline \multirow{2}{*}{ Cancer Type } & \multirow{2}{*}{ Chemotherapeutic Drugs } & \multicolumn{3}{|c|}{ Main Findings } & \multirow{2}{*}{ References } \\
\hline & & & In Vitro & In Vivo/Ex Vivo & \\
\hline \multirow{4}{*}{ Pancreatic cancer } & Gemcitabine & $\begin{array}{l}1 . \\
2 . \\
3 . \\
4 . \\
5 .\end{array}$ & $\begin{array}{l}\text { Inhibition of cell proliferation. } \\
\text { Increased apoptotic activities via the upregulation of } \\
\text { caspase } 3 \text { activity and PARP cleavage; repression of } \\
\text { anti-apoptotic protein Bcl-2, Bcl-xL and IAP-1. } \\
\text { Inhibition of cancer cell migration and invasiveness } \\
\text { via the upregulation of E-cadherin; downregulation of } \\
\mathrm{N} \text {-cadherin and vimentin; downregulation of } \\
\text { MMP-2/9 activities. } \\
\text { Induction of G2/M arrest via the upregulation of p21; } \\
\text { suppression of PCNA. } \\
\text { Inhibited the spheroid-derived cancer stem cell } \\
\text { formation via the suppression of PRC2/PVT1/c-Myc } \\
\text { pathways. }\end{array}$ & $\begin{array}{l}\text { 1. Inhibition of tumor growth via } \\
\text { the downregulation of Ki67, } \\
\text { NF-kB, COX-2, cyclin D1. } \\
\text { 2. Reduction in tumor volume } \\
\text { and weight. } \\
\text { 3. Inhibition of angiogenesis via } \\
\text { the downregulation of } \\
\text { microvessel density marker } \\
\text { CD31 and VEGF. }\end{array}$ & [110-112] \\
\hline & Celecoxib & & $\begin{array}{l}\text { Inhibition of cell proliferation via the downregulation } \\
\text { of COX- } 2 \text {. } \\
\text { Increased apoptotic activities. }\end{array}$ & & [113] \\
\hline & $5-\mathrm{FU}$ & 1. & $\begin{array}{l}\text { Inhibition of cell proliferation. } \\
\text { Reversal of 5-FU-induced chemoresistance via the } \\
\text { inhibition of drug efflux function mediated by MRP5. }\end{array}$ & & [114] \\
\hline & Aspirin, sulforaphane & & $\begin{array}{l}\text { Inhibition of cell proliferation via the upregulation of } \\
\text { ERK } 1 / 2 \text { phosphorylation, p53 and p38 MAPK } \\
\text { proteins; suppression of Akt phosphorylation; } \\
\text { downregulation of NF-kB activity. } \\
\text { Increased apoptotic activities via the upregulation of } \\
\text { caspase } 3 \text { and PARP cleavage. }\end{array}$ & & [115] \\
\hline
\end{tabular}


Table 1. Cont.

\section{Cancer Type}

\begin{tabular}{|c|c|c|c|c|}
\hline \multirow{2}{*}{ Cancer Type } & \multirow{2}{*}{ Chemotherapeutic Drugs } & \multicolumn{2}{|l|}{ Main Findings } & \multirow{2}{*}{ References } \\
\hline & & In Vitro & In Vivo/Ex Vivo & \\
\hline \multirow{4}{*}{ Pancreatic cancer } & $\begin{array}{l}\text { Aspirin, sulforaphane (with } \\
\text { curcumin encapsulated in chitosan } \\
\text { coated solid lipid nanoparticle) }\end{array}$ & & 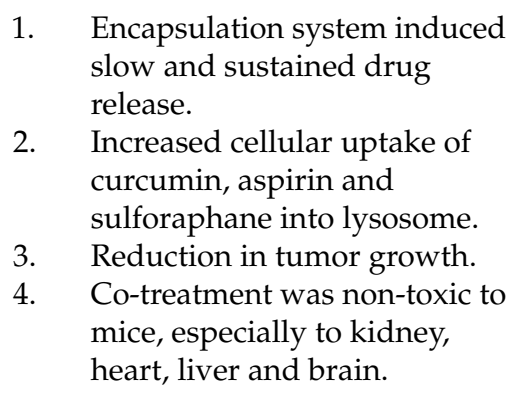 & {$[116,117]$} \\
\hline & Tolfenamic acid & $\begin{array}{l}\text { 1. Inhibition of cell proliferation. } \\
\text { 2. Increased apoptotic activities via the upregulation of } \\
\text { caspase } 3 \text { activity, ROS production and PARP cleavage; } \\
\text { repression of anti-apoptotic protein survivin. } \\
\text { 3. Induction of G0/G1 and G2/M arrest via the } \\
\text { downregulation of NF- } \mathrm{B} \text { translocation to nucleus. }\end{array}$ & & [118] \\
\hline & Garcinol & $\begin{array}{l}\text { 1. Inhibition of cell proliferation. } \\
\text { 2. Increased apoptotic activities via the upregulation of } \\
\text { caspase } 3 / 9 \text { activity. }\end{array}$ & & [119] \\
\hline & $\begin{array}{l}\text { Omega-3 fatty acid, anti-oxidant } \\
\text { Resolvin D1 }\end{array}$ & $\begin{array}{l}\text { 1. Increased apoptotic activities via the upregulation of } \\
\text { caspase } 3 \text { activity. } \\
\text { 2. Increased cytocidal effect of pancreatic cancer cells by } \\
\text { NK cells via the production of IFN- } \gamma \text {. }\end{array}$ & & [120] \\
\hline
\end{tabular}


Table 1. Cont

\section{Cancer Type}

Chemotherapeutic Drugs

\begin{tabular}{ll} 
Cancer Type Chemotherapeutic Drug \\
\hline
\end{tabular}

\begin{tabular}{|c|c|}
\hline \multirow{6}{*}{ Prostate cancer } & Docetaxel \\
\hline & $\begin{array}{l}\text { Docetaxel (with curcumin } \\
\text { encapsulated in EGFR peptide } \\
\text { targeted, pH sensitive nanoparticle) }\end{array}$ \\
\hline & \\
\hline & Metformin \\
\hline & TRAIL \\
\hline & EGCG \\
\hline
\end{tabular}

1. Inhibition of cell proliferation via the downregulation

of NF- $\mathrm{B}$, COX-2, Akt, EGFR, HER2 and CDK-1.

2. Increased apoptotic activities via the activation of

pro-apoptotic protein Bak and Bid; repression of

anti-apoptotic protein Bcl-2, Bcl-xL and Mcl-1.

1. Nanoparticles remained stable and had better

cumulative drug release in $\mathrm{pH} 5.0$ as compared to $\mathrm{pH}$

7.4 .

2. Increased cellular uptake of curcumin and docetaxel via EGFR-mediated endocytosis.

1. Inhibition of tumor growth.

2. Co-treatment was non-toxic to

mice.

References

3. Inhibition of cell proliferation.

1. Inhibition of cell proliferation via the downregulation of mTOR and hTERT.

2. Increased apoptotic activities via the activation of pro-apoptotic protein $\mathrm{Bcl}-\mathrm{xL}$; repression of

In Vivo/Ex Vivo anti-apoptotic protein Bcl-2.

1. Inhibition of cell proliferation via the downregulation

1. Inhibition of tumor growth via the downregulation of NF- $\mathrm{KB}$ of Akt, NF- $\kappa \mathrm{B}$ and I $\kappa \mathrm{B} \alpha$ phosphorylation.

2. Increased apoptotic activities via the upregulation of caspase $3 / 8$ activities; upregulation of DR4 and DR5.

3. Inhibition of angiogenesis via the downregulation of ERK signalling.

2. and Akt phosphorylation.

Increased apoptotic activities [124-126]

detection of high number of

TUNEL positive cells.

1. Inhibition of cell proliferation.

2. Induction of $S$ and $G 2 / M$ arrest via the upregulation of $\mathrm{p} 21$; downregulation of $\mathrm{Rb}$ phosphorylation. 
Table 1. Cont.

\begin{tabular}{|c|c|c|c|c|c|}
\hline \multirow{2}{*}{ Cancer Type } & \multirow{2}{*}{ Chemotherapeutic Drugs } & \multicolumn{3}{|c|}{ Main Findings } & \multirow{2}{*}{ References } \\
\hline & & & In Vitro & In Vivo/Ex Vivo & \\
\hline \multirow{4}{*}{ Prostate cancer } & EGCG, arctigenin & $\begin{array}{l}1 . \\
2 . \\
\\
3 . \\
4 . \\
5 .\end{array}$ & $\begin{array}{l}\text { Inhibition of cell proliferation via the suppression of } \\
\text { STAT3, NF- } \mathrm{B} \text { B and Akt phosphorylation. } \\
\text { Increased apoptotic activities via the activation of } \\
\text { pro-apoptotic protein Bax; repression of anti-apoptotic } \\
\text { protein Bcl-2. } \\
\text { Induction of G0/G1 arrest. } \\
\text { Inhibition of cancer cell migration. } \\
\text { Harmless to normal epithelial cells. }\end{array}$ & & [128] \\
\hline & Resveratrol & & & $\begin{array}{l}\text { 1. Inhibition of tumor growth. } \\
\text { 2. Increased apoptotic activities. } \\
\text { 3. Increase in anti-oxidant } \\
\text { activities via the upregulation } \\
\text { of GSH, SOD, GST and GR } \\
\text { activities. }\end{array}$ & [129] \\
\hline & Resveratrol, ursolic acid & 1. & $\begin{array}{l}\text { Inhibition of cell proliferation via the suppression of } \\
\text { ATP activities; the release of ROS. }\end{array}$ & $\begin{array}{l}\text { 1. Inhibition of tumor growth via } \\
\text { the downregulation of Src, } \\
\text { mTORC1 and STAT3 } \\
\text { phosphorylation; suppression } \\
\text { of AMPK activation. } \\
\text { 2. Decrease in tumor volume and } \\
\text { weight of mice. }\end{array}$ & [130] \\
\hline & Quercetin & & $\begin{array}{l}\text { Inhibition of cell proliferation via the upregulation of } \\
\text { p21 and p27. } \\
\text { Increased apoptotic activities via the activation of } \\
\text { pro-apoptotic protein Bax; upregulation of caspase } 3 \\
\text { activity. } \\
\text { Reversal of androgen deprivation therapy-induced } \\
\text { chemoresistance via the upregulation of AR protein; } \\
\text { downregulation of DNMT activity. }\end{array}$ & & [131] \\
\hline
\end{tabular}


Table 1. Cont.

Cancer Type Chemotherapeutic Drugs

5-FU

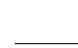

Celecoxib

Liver cancer

Metformin

1. Inhibition of cell proliferation via the suppression of NF- $\kappa \mathrm{B}$ translocation from cytoplasm to nucleus; downregulation of COX-2 expression.

Main Findings

In Vivo/Ex Vivo

1. Inhibition of tumor growth.

2. Co-treatment was non-toxic to [132] mice.

1. Inhibition of cell proliferation via the downregulation of NF- $\kappa \beta$, PGE2, MDA and Akt phosphorylation; suppression of cyclin D1 and VEGF expression.

2. Increased apoptotic activities via the upregulation of caspase 3 activity.

1. Inhibition of cell proliferation via the upregulation of PTEN and p53; downregulation of NF- $\mathrm{kB}$, Akt and mTOR phosphorylation.

2. Harmless to normal cell lines.

3. Increased apoptotic activities via the repression of anti-apoptotic protein Bcl-2; activation of pro-apoptotic protein Bax; upregulation of PARP cleavage.

4. Inhibition of cancer cell migration and invasiveness via the downregulation of VEGF and EGFR proteins

5. Inhibition of angiogenesis via the reduction in the number of HUVEC.
1. Inhibition of tumor growth.

2. Increased apoptotic activities via the elevation of Bax/Bcl-2 ratio.

3. Inhibition of angiogenesis via the reduction in VEGF expression.
References

Inhibition of cell proliferation.

2. Increased apoptotic activities via the activation of

pro-apoptotic protein Bax; repression of anti-apoptotic

protein Bcl-2; upregulation of caspase 9 activity. 
Table 1. Cont

\section{Cancer Type}

Chemotherapeutic Drugs

Doxorubicin, etoposide

Gastric cancer
Inhibition of cell pro
COX-2 and NF-kB

Inhibition of cell proliferation

2. Increased apoptotic activities via the upregulation of

DR5 and TRAIL/Apo2L.

\section{BCG}

Bladder cancer
3. Reversal of BCG-induced chemoresistance via the suppression of NF- $\mathrm{k} \beta$.
1. Inhibition of cell proliferation via the repression of anti-apoptotic protein Bcl-2.

2. Reversal of doxorubicin and etoposide-induced

chemoresistance via the suppression of NF- $\mathrm{kB}$ and

I $\mathrm{B} \mathrm{\alpha} \alpha$ degradation.
1. Inhibition of tumor growth.

2. Co-treatment was non-toxic to [137] mice.

\section{References}

Inhibition of tumor growth via

the suppression of

NF- $\kappa$ B-related gene products

such as cyclin D1 and c-Myc.

2. Inhibition of tumor volume

via the suppression of

proliferation marker Ki67 and

microvessel density marker

CD31 and VEGF.

3. Increased apoptotic activities

via the suppression of

anti-apoptotic protein Bcl-2

and survivin; upregulation of

pro-apoptotic protein $\mathrm{Bcl}-\mathrm{xL}$.

1. Inhibition of cell proliferation via the upregulation of ERK and MEK phosphorylation; upregulation of p53 and p21; elevation of STAT3 phosphorylation.

1. Inhibition of tumor growth.

Cisplatin

2. Increased apoptosis via the production of ROS

2. Co-treatment was non-toxic to

repression of anti-apoptotic protein $\mathrm{Bcl}-2$ and XIAP.

mice.

3. Inhibition of cancer cell migration. 
Table 1. Cont.

\begin{tabular}{|c|c|c|c|c|c|}
\hline \multirow{2}{*}{ Cancer Type } & \multirow{2}{*}{ Chemotherapeutic Drugs } & \multicolumn{3}{|c|}{ Main Findings } & \multirow{2}{*}{ References } \\
\hline & & & In Vitro & In Vivo/Ex Vivo & \\
\hline \multirow{2}{*}{$\begin{array}{l}\text { Acute lymphoblastic } \\
\text { leukemia }\end{array}$} & Imatinib & $\begin{array}{l}1 . \\
2 . \\
3 .\end{array}$ & $\begin{array}{l}\text { Inhibition of cell proliferation via the downregulation } \\
\text { of Akt/mTOR pathway and suppression of BCR/ABL. } \\
\text { Increased apoptosis via the repression of } \\
\text { anti-apoptotic protein Bcl-2; activation of } \\
\text { pro-apoptotic protein Bax. } \\
\text { Harmless to normal cell lines. }\end{array}$ & $\begin{array}{l}\text { 1. Inhibition of tumor growth via } \\
\text { the suppression of BCR/ABL. } \\
\text { Reduction in leukemia burden } \\
\text { via the reduction in leukemic } \\
\text { infiltration into the spleen. }\end{array}$ & [140] \\
\hline & Imatinib, vincristine & $\begin{array}{l}1 . \\
2 . \\
3 .\end{array}$ & $\begin{array}{l}\text { Inhibition of cell proliferation via the suppression of } \\
\text { VEGF and CCND1. } \\
\text { Reversal of imatinib and vincristine-induced } \\
\text { chemoresistance via the downregulation of NF- } \kappa \text { B. } \\
\text { Increase apoptosis via the repression of anti-apoptotic } \\
\text { protein Bcl-2. }\end{array}$ & & [141] \\
\hline Acute myeloid leukemia & Thalidomide & $\begin{array}{l}1 . \\
2 .\end{array}$ & $\begin{array}{l}\text { Inhibition of cell proliferation via the downregulation } \\
\text { of STAT3. } \\
\text { Increased apoptosis via the repression of } \\
\text { anti-apoptotic protein Bcl-xL. }\end{array}$ & & [142] \\
\hline
\end{tabular}


Table 1. Cont.

Cancer Type

Chemotherapeutic Drugs

\section{Main Findings}

In Vivo/Ex Vivo
References

1. Inhibition of cell proliferation.

2. Increased apoptosis via the repression of

Chronic myeloid leukemia Quercetin

anti-apopto

cleavage; upregulation of caspase 9 activity; elevation

in cytochrome $c$ release; enhanced ROS production;

elevated loss of mitochondrial membrane potential;

decrease in intracellular GSH.

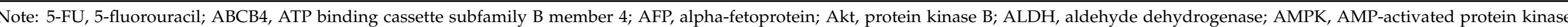

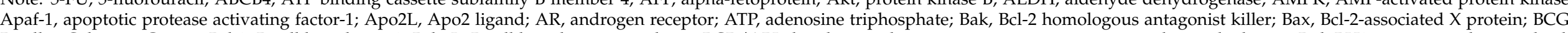

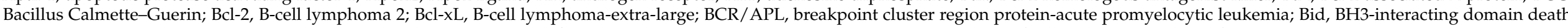

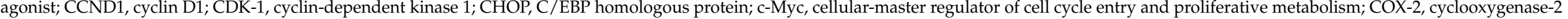

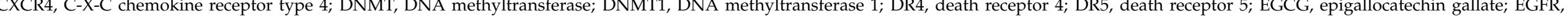

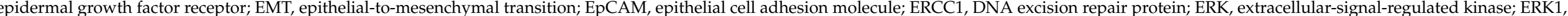

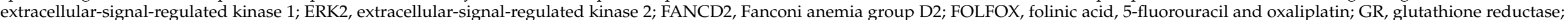

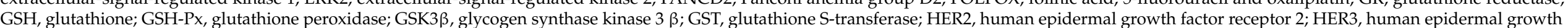

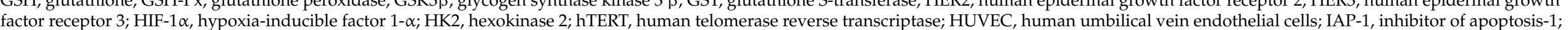

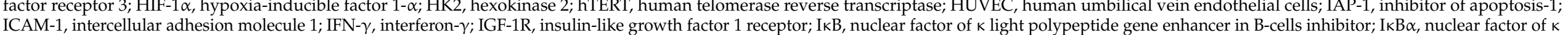

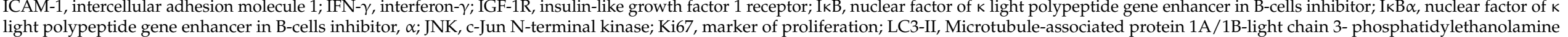

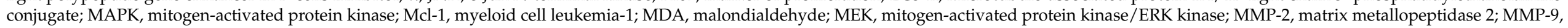

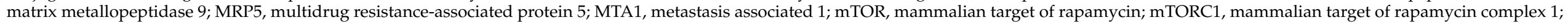

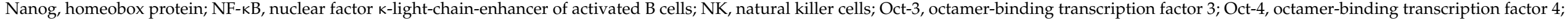

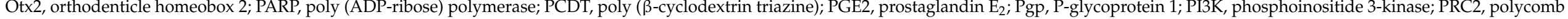

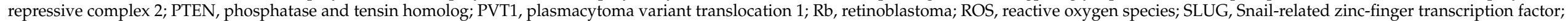

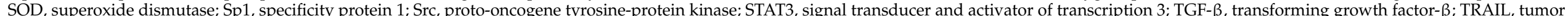

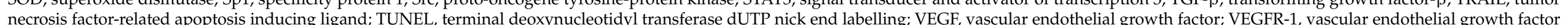
receptor-1; Wnt, wingless-related integration site. 


\subsection{Curcumin Combination Therapy in Breast Cancer}

Compelling evidence has demonstrated the benefits of curcumin combination therapy as compared to monotherapy in breast cancer. As a selective estrogen receptor modulator, tamoxifen is renowned for the treatment of hormone-positive breast cancer [144]. Nonetheless, repeated treatments confer chemoresistance, attributed to the dysregulation of cell cycle and interruption on multiple signal transduction pathways [145]. An in vitro investigation reveals that the co-administration of curcumin and 4-hydroxytamoxifen (4-OHT), a metabolite of tamoxifen, could restore the sensitivity of 4-OHT of HR-positive MCF-7 cells through the downregulation of cyclin D1 and upregulation of p21. Concomitantly, the cell proliferative effect was reduced significantly via the repression of Akt/mTOR signalling pathways. Compared to either curcumin or 4-OHT alone, combined treatment also remarkably activated pro-apoptotic protein $\mathrm{Bcl}-\mathrm{xL}$ and suppressed the $\mathrm{Bcl}-2$ proteins, thereby further enhancing the apoptotic activities [65].

Apart from that, the Snail-related zinc-finger transcription factor (SLUG) overexpression, which is correlated to poor prognosis in various cancers [146,147], has been linked to tamoxifen resistance in breast cancer therapy [146]. The phenomenon was reversed with the combined treatment of curcumin and 4-OHT in MDA-MB-231 cells. Besides weakening mTOR activities, the reversal of chemoresistance was accompanied by enhanced mitochondrial-mediated apoptosis and the downregulation of hexokinase 2 (HK2) activities, therefore mediating cell death and preventing the metastatic behaviour of breast cancer cells, respectively [66].

Human epidermal growth factor receptor-2 (HER2) overexpression accounts for $15-30 \%$ of metastatic breast cancer, which exacerbates aberrant cell proliferation and cell survival in breast cancer patients [148]. To date, trastuzumab, an anti-HER2 monoclonal antibody, serves as the most efficacious targeted therapy in treating HER2-related breast cancer [149]. It was shown to be able to maximize its therapeutic potential when combined with other anticancer agents $[150,151]$. Through cell proliferation and cell cycle analysis, co-treatment of curcumin $(10 \mu \mathrm{g} / \mathrm{mL})$ and trastuzumab $(10 \mu \mathrm{g} / \mathrm{mL})$ significantly reduced cell proliferation and induced G2/M arrest in HER2-overexpressed BT-474 and SK-BR-3-hr (a herceptin resistant strain from SK-BR-3) breast cancer cells, compared to trastuzumab alone. This was accompanied by the suppression of HER2 expression with the inhibition of downstream targets such as NF- $\mathrm{kB}, \mathrm{Akt}$ and MAPK signalling pathways. Further in vivo study revealed that BT-474 xenograft mice models had the smallest tumor volume after 4 weeks of curcumin $(45 \mathrm{mg} / \mathrm{kg})$ and trastuzumab $(4 \mathrm{mg} / \mathrm{kg})$ co-treatment, when compared to curcumin or trastuzumab alone [67].

Curcumin also serves as a potential adjuvant with other chemotherapeutic agents in augmenting anticancer effects. The combined treatment of curcumin and paclitaxel significantly suppressed the paclitaxel-mediated NF- $\kappa B$ expression and its regulatory genes COX-2, matrix metallopeptidase 9 (MMP-9), VEGF, and intercellular adhesion molecule 1 (ICAM-1), thus promoting the anti-proliferative and anti-metastatic behaviour in breast cancer cells $[68,152]$. Interestingly, further experiments proved that curcumin and paclitaxel curbed the metastasis of MDA-MB-435 breast cancer cells to lung tissues in xenograft mice models [69]. More importantly, this combination of curcumin (ranging from 25-225 mg/kg) and paclitaxel $(5 \mathrm{mg} / \mathrm{kg}$ ) was found to be safe and induced no toxicity effects in mice models [68].

Hindered by drug efflux and chemoresistance, doxorubicin was explored in combination with curcumin in breast cancer treatment [26]. A study reported that this co-treatment profoundly blocked the drug efflux function, as influenced by ATP binding cassette subfamily B member 4 (ABCB4) [72]. Additionally, the co-delivery of doxorubicin with curcumin loaded in solid lipid nanoparticles was shown to inhibit the tumor growth in mice by decreasing the P-gp surface expression besides increasing intracellular retention of doxorubicin. This has successfully augmented the cytotoxicity effect on breast cancer cells [73]. Besides, another study illustrated that curcumin inhibited the doxorubicin-induced EMT via the suppression of Akt, $\beta$-catenin and glycogen synthase kinase $3 \beta$ (GSK3 $\beta$ ) pro- 
tein expression, emphasizing the importance of the combined treatment of curcumin and doxorubicin in inhibiting the metastasis of breast cancer cells [153].

Apart from the combination with chemotherapeutic agents, the combined treatment of curcumin with other natural compounds has also been investigated in breast cancer. Flow cytometry cell death analysis showed that the co-treatment of curcumin $(5 \mu \mathrm{M})$ and berberine $(25 \mu \mathrm{M})$ synergistically exerted apoptosis and autophagy cell death to MDA-MB-231 and MCF7 breast cancer cells [76]. Moreover, curcumin $(1.5 \mu \mathrm{M})$ sensitized the AU565 breast cancer cells treated with quercetin $(4 \mu \mathrm{M})$ and optiberry $(2 \mu \mathrm{g} / \mathrm{mL})$ to decrease lapatinib-mediated HER2 overexpression via the downregulation of HER2/Akt signalling pathways [74]. Another study reported the benefits of curcumin $(200 \mathrm{mg} / \mathrm{kg})$ and epigallocatechin gallate (EGCG) $(25 \mathrm{mg} / \mathrm{kg})$ in lowering the tumour burden of xenograft models via the reduction in phosphorylated Akt, EGFR and vascular endothelial growth factor receptor-1 (VEGFR-1) expression, highlighting the enhanced anticancer potential of this treatment regimen [75].

\subsection{Curcumin Combination Therapy in Colorectal Cancer}

To date, 5-fluorouracil (5-FU) remains one of the first-line treatments for colorectal cancer patients. Unfortunately, its clinical efficacy was limited by the low (about 10-15\%) overall response in metastatic colorectal cancer patients [154]. Moreover, the toxicity experienced with increasing dosage of 5-FU has caused further constraints on the treatment [155]. Growing evidence has proven the role of curcumin in benefiting the chemotherapeutic efficacy of colorectal cancer preclinically. For instance, the toxicity profile was alleviated when the co-treatment of $5 \mu \mathrm{M}$ curcumin lowered the concentration of 5-FU $(0.01 \mathrm{nM}$; originally $10 \mathrm{nM}$ ) required in diminishing the cell proliferation of 3D cell culture models [77]. Concurrently, this was associated with G0/G1 cell cycle arrest via cyclin D1 inactivation $[78,79]$. Another cell cycle study showed that the co-treatment of curcumin and 5-FU caused S phase arrest in 5-FU-resistant HCT116 cell lines, implying that the regulation of cell cycle is cell-specific [80]. Furthermore, invasion assays revealed that this treatment combination reduced the migratory behaviour of colorectal cancer cells via the inhibition of MMP-9 and C-X-C chemokine receptor type 4 (CXCR4) expression, the downregulation of NF- $\mathrm{KB}$ expression, and disruption of ten-eleven translocation methylcytosine dioxygenase 1 (TET1)-naked cuticle homolog 2 (NKD2)-Wnt signalling pathways [77,79]. Apart from that, they also promoted the apoptotic activities in colon cancer cells via the upregulation of Bax and the cleavage of caspase 3, 8 and 9 [78,80]. Another study proved that 5-FU-induced autophagy was inhibited in HCT116 and HT29 colon cancer cells co-treated with curcumin and 5-FU, via the downregulation of Akt and mTOR activities [81]. The progression of 5-FU therapeutic resistance, either intrinsically or by repeated treatments, had exacerbated the uncontrolled cell division and survival of colorectal cancer cells via the elevation of prooncogenic NF- $\mathrm{kB}$, Wnt and PI3K/proto-oncogene tyrosine-protein kinase (Src) signalling. However, this phenomenon was resolved when the colorectal cancer cells were co-treated with curcumin and 5-FU $[77,79,80]$.

Other FDA-approved standard chemotherapeutic agents for colorectal cancer treatment include oxaliplatin, dasatinib and irinotecan [155]. Several preclinical studies demonstrated the improvement in therapeutic efficacy of colorectal cancer cells when these chemotherapeutic agents are co-administered with curcumin. In addition to increased growth inhibitory effects, the combined treatment of curcumin and other chemotherapeutic drugs, such as oxaliplatin or irinotecan, significantly promoted apoptotic activities in HT29 and HCT116 colon cancer cells via the increased reactive oxygen species (ROS) production and the upregulation of endoplasmic reticulum-associated protein C/EBP homologous protein (CHOP) $[82,83]$. Besides, the suppression of TGF- $\beta$, Smad- 2 and N-cadherin indicated the EMT abolishment in colorectal cancer cells co-treated with curcumin and oxaliplatin $[82,84,85]$. The presence of CSCs in tumor microenvironment supports the notion of therapeutic failure and resistance. Therefore, targeting the CSCs can prevent cancer recurrence followed by tumor eradication [156]. The repeated administration of 
dasatinib and irinotecan has been shown to cause chemotherapeutic resistance in colorectal cancer cells. The co-administration of these drugs with curcumin had inhibited the sphereforming potential of colorectal CSC through the downregulation of CSC markers, such as CD44, CD133, epithelial cell adhesion molecule (EpCAM) and CD24, indicating that curcumin can alleviate the cancer progression by interrupting with CSCs activities when co-treated with other chemotherapy agents [84,85].

The combined treatment of multiple conventional chemotherapeutic agents has produced positive clinical outcomes in colorectal cancer patients to some extent. However, despite the improved overall survival and response rate initially, gradual irresponsiveness to repetitive treatment and modest toxicity were also experienced by the patients [155]. The combination of 5-FU and oxaliplatin were shown to elevate the expression of tumourpromoting proteins, such as EGFR, HER2, human epidermal growth factor receptor 3 (HER3), Akt and COX2, which rendered the cell survival and uncontrolled cell proliferation in chemo-surviving cells. Nevertheless, these tumor-promoting effects were curbed by the co-administration of curcumin $[86,87]$. Interestingly, the supplementation of curcumin increased the expression of insulin-like growth factor-binding protein 3 (IGFBP3) and promoted the binding between IGFBP3 and insulin-like growth factor 1 (IGF-1), sequestering the activation of IGF-1 and inhibiting the IGF-1/insulin-like growth factor type 1 receptor (IGF-1R) signalling, in 5-FU and oxaliplatin-treated colorectal cancer cells $[86,87,94,95]$. Furthermore, ex vivo spheroid cultures showed a great reduction in cell proliferation and the decreased expression of stem cell markers, such as Nanog, vascular endothelial growth factor receptor-2 (VEGFR-2) and octamer-binding transcription factor 4 (Oct4), with the combined treatment of 5-FU and oxaliplatin with curcumin. Further clinical studies have demonstrated that curcumin supplementation of $0.5-2 \mathrm{~g} /$ day to $5-\mathrm{FU}$ - and oxaliplaitintreated patients were clinically safe [88]. Moreover, the co-administration of curcumin and 5-FU and oxaliplatin significantly suppressed EGFR signalling via the increased methylation status of EGFR, emphasizing the role of curcumin in the epigenetic modulation of colon cancer cells [89]. On the other hand, the combination of bevacizumab $(0.4 \mathrm{mg} / \mathrm{kg})$ and turmeric extract (with absorbable curcumin) $(400 \mathrm{mg} / \mathrm{kg}$ ) caused an inhibition of angiogenesis while promoting apoptosis in the tumor area in the xenograft model. Besides, the absence of systemic toxicity to the liver, kidney and heart in in vivo models signifies the safety and tolerability of this combined therapy [90].

Montgomery et al. (2016) reported that curcumin potentiated the anticancer effects of other natural compounds, where curcumin $(12.5 \mu \mathrm{M})$ and silymarin $(12.5 \mu \mathrm{M})$ synergistically augmented the apoptosis of DLD-1, HCT116 and LoVo colon cancer cells with increased caspase $3 / 7$ activities, as compared to monotherapy [91]. Another study involving (3-(4,5-dimethylthiazol-2-yl)-2,5-diphenyltetrazolium bromide) tetrazolium (MTT) assay and cell cycle analysis revealed that the co-treatment of curcumin $(10 \mu \mathrm{M})$ and resveratrol $(10 \mu \mathrm{M})$ showed synergistic anticancer effects in HCT116 colon cancer cells by inhibiting cell proliferation and inducing $S$ phase arrest. This was associated with the reduction in oncogenic protein expression, notably EGFR, HER2, HER3 and IGF-1R levels. Further in vivo studies confirmed tumor growth reduction without any systemic toxicity, indicating the safety of curcumin and resveratrol [92].

\subsection{Curcumin Combination Therapy in Lung Cancer}

Current standard chemotherapeutic agents for non-small-cell lung carcinoma (NSCLC) patients are TKIs, such as gefitinib and erlotinib. Chemoresistance towards this treatment is becoming more prevalent, where the abnormal amplification of EGFR was massively identified in NSCLC patients [157]. Flow cytometric apoptotic analysis revealed that the co-treatment of curcumin $(10 \mathrm{ng} / \mathrm{mL})$ and gefitinib $(0.1 \mathrm{~mol} / \mathrm{L})$ significantly augmented the apoptosis in NCI-H1975 lung cancer cells by blocking EGFR signalling pathways, notably Akt and ERK1/2 phosphorylation [93]. Apart from enhancing apoptosis, the co-treatment of curcumin and gefitinib induced autophagy-related cell death, which was associated with the suppression of histone deacetylase activities and the proteasomal degradation of EGFR 
proteins. Interestingly, in vivo studies confirmed a decrease in tumor weight of xenograft models as compared to control, through the reduced expression of oncogenic proteins EGFR, Akt and cyclin D1, and enhanced caspase 3/8 activities, while being harmless to other tissues in xenograft models [94,95]. Similar to gefitinib, erlotinib $(1 \mu \mathrm{M})$ elevated its apoptotic effects to PC-9 lung cancer cells when co-administered with curcumin $(25 \mu \mathrm{M})$ through the elevation of caspase 3 activities and the downregulation of EGFR proteins. In vivo studies further confirmed that the reduction of tumor growth was associated with the downregulation of NF- $\mathrm{KB}[96,97]$.

Platinum-based chemotherapy, such as cisplatin and carboplatin, forms the standard chemotherapy regimen in the advanced stage of lung cancer. Despite yielding better overall survival, these treatment regimens are often associated with undesirable toxicity and the relapse of lung cancer [158]. Studies on lung cancer cells showed that curcumin treatment could lower the concentration of cisplatin needed to achieve the same cytotoxicity effect when compared to cisplatin monotherapy $[98,99]$. This was supported by the reduction in cisplatin-induced thymidine phosphorylase (TP) and excision repair 1, endonuclease non-catalytic subunit (ERCC1)-related signalling such as PI3K/Akt/Snail signalling [100]. Additionally, the co-treatment of curcumin and cisplatin synergistically elevated apoptotic activities in A549 lung cancer cells, mainly via the upregulation of tumor suppressor proteins p53, p21 and downregulation of oncogenic proteins EGFR, HIF- $1 \alpha, \mathrm{NF}-\mathrm{kB}, \mathrm{Akt}$, mTOR [99-101]. A transwell invasion study revealed that the co-treatment of curcumin and cisplatin diminished the invasiveness of lung CSCs that are the main drivers of tumor invasion and chemoresistance [102,103]. Likewise, the decrease in invasiveness was also observed when lung cancer cells were co-treated with curcumin $(10 \mu \mathrm{M})$ and carboplatin (50 or $100 \mu \mathrm{M}$ ), through the repression of matrix metallopeptidase 2/9 (MMP2/9) activities [104].

Other chemotherapeutic agents were also reported to have boosted anticancer effects when co-administered with curcumin. Cell survival assays demonstrated that curcumin $(30 \mu \mathrm{M})$ enhanced the cytotoxicity of paclitaxel $(30 \mu \mathrm{M})$ in paclitaxel-resistant A549 and H460 lung cancer cells through the suppression of microRNA-30c-5p-mediated metastasisassociated protein 1 (MTA1), which further limited the metastasis behaviour in lung cancer cells [105]. Besides, the co-delivery of curcumin and paclitaxel encapsulated in poly (B-cyclodextrintriazine) (PCDT) exerted the synergistic inhibition of clonogenic formation and increased apoptotic events in H1299 lung cancer cells, with better solubility, bioavailability and stability provided by the PCDT delivery system [106]. Doxorubicin, which is notorious for its cardiotoxicity, is also challenged by multidrug resistance development [107]. These problems were improved with a nanomicelle delivery system encapsulating both doxorubicin and curcumin, which was responsible for promoting endocytosis and increasing drug-release capacity, while being harmless to the normal cells in vitro and in vivo [107-109].

\subsection{Curcumin Combination Therapy in Pancreatic Cancer}

In pancreatic cancer, the co-treatment of curcumin and gemcitabine synergistically promoted apoptosis via the downregulation of NF- $\mathrm{kB}$. Furthermore, the invasiveness of pancreatic cancer cells was diminished through the downregulation of $\mathrm{N}$-cadherin, vimentin and the upregulation of E-cadherin [110]. Immunohistochemistry analysis indicated the decreased expression of EMT markers MMP-9, ICAM-1 and COX-2, suggesting a reduced metastasis behaviour in xenograft models co-treated with curcumin and gemcitabine. Furthermore, the inhibition of angiogenesis was observed in xenograft models via the suppressed expression of CD31 microvessel density marker [111]. Another study demonstrated that co-treatment of curcumin $(20 \mu \mathrm{M})$ and gemcitabine $(50 \mathrm{nM})$ remarkedly impeded the formation of spheroid-derived CSCs by inhibiting the polycomb repressive complex 2 (PRC2)/plasmacytoma variant translocation 1 (PVT1)/cellular-myelocytomatosis (c-Myc) axis [112]. The high level of multidrug resistance-associated protein 5 (MRP5) in pancreatic 
cancer cells was profoundly repressed by the co-treatment of curcumin and 5-FU, implying that curcumin potentiates the sensitivity of 5-FU to pancreatic cancer cells [114].

Lev-Ari et al. (2005) showed that the combined treatment of curcumin $(15 \mu \mathrm{M})$ and celecoxib $(25 \mu \mathrm{M})$ significantly reduced the cell proliferation and enhanced apoptotic effects in P-34 pancreatic cancer cells by suppressing COX-2 expression, as compared to celecoxib monotherapy [113]. The chemoprevention of curcumin $(7.5 \mu \mathrm{M})$ and tolfenamic acid $(50 \mu \mathrm{M})$ synergistically stimulated the apoptotic effects in pancreatic cancer cells via the downregulation of survivin and suppression of specificity protein 1 (Sp1). Additionally, this treatment regimen induced G1 and G2 cell cycle arrest with lesser translocation of NF- $\mathrm{kB}$ into the nucleus, implying a diminished cell proliferation [115].

In another study, cell death analysis illustrated that the combined treatment of curcumin $(10 \mu \mathrm{M})$ and sulforaphane $(5 \mu \mathrm{M})$ significantly enhanced the apoptotic effect of pancreatic cancer cells treated with aspirin $(1 \mathrm{mM})$. With the decrease in cell survival, this chemoprevention regimen successfully impeded Akt phosphorylation and NF- $\kappa B$ activity [116]. Further maximizing the therapeutic efficacy, this co-treatment regimen was encapsulated in chitosan-coated solid lipid nanoparticles for better drug delivery in xenograft models. Apart from exhibiting no toxicity, this delivery system also demonstrated slow and sustained drug release profile, and thereby significantly lessened the tumor progression in in vivo studies $[117,118]$. On the other hand, apoptotic activity was synergistically augmented when BxPC-3 and Panc-1 pancreatic cancer cells co-treated with garcinol and curcumin showed elevated caspase 3/9 activities [119]. In a study investigating curcuminoids emulsified in omega- 3 fatty acids combined with anti-oxidant Resolvin D1, it was revealed that the combination significantly induced apoptosis in pancreatic cancer cells via the activation of caspase 3 activity. Furthermore, this combined treatment potentiated the cytotoxicity effect and inhibited interferon $\gamma($ IFN $\gamma$ ) production in NK cells when co-cultured with pancreatic cancer cells [120].

\subsection{Curcumin Combination Therapy in Prostate Cancer}

Although the early stage of prostate cancer can be managed well with radiation and surgery, many patients eventually progress into metastatic prostate cancer due to irresponsiveness to androgen deprivation therapy (ADT) and chemotherapy resistance. This translates to the poor prognosis of prostate cancer patients $[159,160]$. Despite being approved by the FDA, the combination of docetaxel with prednisone or estramustine only demonstrated modest clinical benefits to prostate cancer patients [161]. The combined treatment of curcumin $(20 \mu \mathrm{M})$ and docetaxel $(10 \mathrm{nM})$ potentiated apoptotic effects in PC3 prostate cancer cells through the downregulation of Bcl-2, Bcl-xL, and Mcl-1 and upregulation of Bak and Bid. Furthermore, the decrease in cell proliferation was correlated with the reduced CDK1, Akt, EGFR, and HER2 expression [121]. An EGFR-targeted nanoparticle delivery system containing curcumin $(0.58 \mu \mathrm{M})$ and docetaxel $(0.058 \mu \mathrm{M})$ was developed to induce EGFR-mediated endocytosis in prostate cancer cells [162]. Besides being stable, this delivery system also successfully reduced the tumor burden of xenograft models without causing any systemic toxicity [122].

In recent years, tumor necrosis factor-related apoptosis-inducing ligand (TRAIL) has become an attractive therapeutic agent in combating cancer through apoptosis. Current evidence showed limited positive outcomes in several clinical studies, mainly due to its poor agonist activity [163]. Despite being proven to be safe and cause no toxicity to normal tissues, TRAIL was profoundly correlated with its therapeutic resistance in cancer cells [22,164]. Therefore, a sensitizer plays an important role in overcoming TRAIL resistance. Curcumin has been shown to be able to sensitize TRAIL-resistant prostate cancer cells to TRAIL through the upregulation of death receptors death receptor 4 (DR4), death receptor 5 (DR5) and inhibited angiogenesis [164]. Similarly, another flow cytometry cell death analysis demonstrated that the combination of curcumin $(10$ or $25 \mu \mathrm{mol} / \mathrm{L})$ and TRAIL $(20 \mathrm{ng} / \mathrm{mL}$ ) remarkedly induced apoptotic activities in LNCaP prostate cancer cells by downregulating NF- $\mathrm{KB}$ and suppressing nuclear factor of $\mathrm{\kappa}$ light polypeptide gene 
enhancer in B-cells inhibitor, $\alpha\left(\mathrm{I}_{\kappa} \mathrm{B} \alpha\right)$ phosphorylation [125]. Another in vivo experiment exhibited that the co-treatment of curcumin $(50 \mathrm{mg} / \mathrm{kg})$ and TRAIL $(3 \mathrm{mg} / \mathrm{kg})$ caused a significant reduction in tumor burden through downregulating Akt and NF- $\mathrm{KB}$ expressions [126]. Interestingly, these reports highlighted no toxicity effect in preclinical models, further proving the potential of curcumin and TRAIL combination as a safe and tolerable alternative treatment for prostate cancer in future $[125,126]$.

The work by Eslami et al. (2020) showed that the combination treatment of curcumin $(25 \mu \mathrm{M})$ and metformin $(4 \mathrm{mM})$ synergistically elevated apoptotic activities with the downregulation of mTOR activities in LNCaP prostate cancer cells [123]. In terms of combination with other natural compounds, curcumin $(50 \mu \mathrm{M})$ and epigallocatechin gallate (EGCG) $(100 \mu \mathrm{M})$ collectively inhibited the proliferation of PC3 prostate cancer cells by causing G2/M and S phase arrest, which was linked to an elevation of p21 protein and reduced phosphorylation of retinoblastoma (Rb) [127]. Another study involving cell death analysis demonstrated that the supplementation of curcumin $(5$ to $10 \mu \mathrm{M})$ with arctigenin $(1 \mu \mathrm{M})$ and EGCG $(40 \mu \mathrm{M})$ synergistically induced apoptosis in LNCaP prostate cancer cells without affecting normal epithelial cells. The apoptotic effect was enhanced by an elevation of Bax/Bcl-2 ratio and a reduction in Akt and signal transducer and activator of transcription 3 (STAT3) phosphorylation [128]. Additionally, the co-administration of curcumin $(60 \mathrm{mg} / \mathrm{kg})$ and resveratrol $(5.7 \mathrm{mg} / \mathrm{mL})$ ameliorated the tumor burden of prostate cancer xenograft models via an elevated expression of tumour suppressor proteins and anti-oxidant activities [129]. Similarly, the co-treatment of curcumin with resveratrol and ursolic acid, respectively, worked in synergy to reduce the tumour volume of xenograft models, along with the decrease in mammalian target of rapamycin complex 1 (mTORC1) and signal transducer and activator of transcription (STAT) activities [130]. The combined treatment of curcumin $(8.9 \mu \mathrm{M})$ and quercetin $(8.9 \mu \mathrm{M})$ reversed the hypermethylation status of androgen receptor (AR) proteins that conferred ADT resistance, by restraining the activities of DNA methyltransferase. Hence, this led to enhanced AR-mediated apoptosis in prostate cancer cells [131].

\subsection{Curcumin Combination Therapy in Other Cancers}

Curcumin synergism for cancer treatment has also been studied in various other cancers. For instance, the co-treatment of curcumin $(4.32 \mu \mathrm{mol} / \mathrm{L})$ and $5-\mathrm{FU}(2.16 \mu \mathrm{mol} / \mathrm{L})$ exhibited a synergistic effect on the anti-proliferation of HepG2 hepatocellular carcinoma cells via the inhibition of NF- $\mathrm{KB}$ translocation from cytoplasm to nucleus. Concurrently, this co-treatment also suppressed the expression of COX-2 protein, thereby disrupting the uncontrolled cell survival [132]. In another study, the combined administration of curcumin $(13 \mu \mathrm{M})$ and celecoxib $(42.8 \mu \mathrm{M})$ synergistically induced apoptosis in liver cancer cells by elevating caspase 3 activity. Cell proliferation assay revealed that HepG2 hepatocellular carcinoma cells also exhibited a great reduction in the expression of cell survival proteins, such as Akt, NF-kB p65 and malondialdehyde (MDA), and the inhibition of VEGF expression, implying the potentiation of anti-proliferative and anti-angiogenesis effects by curcumin and celecoxib co-treatment [133]. Zhang et al. (2018) tested the combination of curcumin $(10 \mu \mathrm{M})$ and metformin $(10 \mathrm{mM})$, and found that it induced a synergistic anti-proliferative effect on HepG2 hepatocellular carcinoma cells, without harming any normal cell lines. This anti-proliferative effect was attributed to the reexpression of tumor suppressor protein phosphatase and tensin homolog (PTEN) and p53. In vivo studies further confirmed that the co-treatment enhanced apoptosis activities via the upregulation of $\mathrm{Bax} / \mathrm{Bcl}-2$ ratio and elicited anti-angiogenesis effect via the downregulation of VEGF expression [134].

Although the incidence has declined steadily in the last few decades, gastric cancer still constitutes a global health issue as concerned by a low median survival rate of less than 12 months in gastric cancer patients [165]. Numerous studies suggested the potential of combination therapy to improve the clinical outcome of gastric cancer. Doxorubicin or etoposide repeated treatments led to the aberrant amplification of NF- $\mathrm{KB}$, resulting 
in therapeutic resistance in gastric cancer cells. This problem was resolved by the pretreatment of curcumin $(40 \mu \mathrm{mol} / \mathrm{L})$ followed by doxorubicin $(0.3 \mu \mathrm{mol} / \mathrm{L})$ or etoposide $(20 \mu \mathrm{mol} / \mathrm{L})$ administration [136]. Similarly, curcumin and doxorubicin co-treatment showed significantly more induction of apoptosis and anti-mobility behaviour of AGS gastric cancer cells as compared to monotherapy and the untreated control [135]. In vivo studies also highlighted the benefits of curcumin $(74 \mathrm{mg} / \mathrm{kg})$ and $5-\mathrm{FU}(52 \mathrm{mg} / \mathrm{kg})$ coadministration in slowing down the tumor growth via the reduced expression of NF- $\mathrm{kB}$ and COX-2, without causing any toxicity effects in other body parts of gastric cancer xenograft models [137].

Being the gold standard intravesical immunotherapy for bladder cancer, Bacillus Calmette-Guerin (BCG) treatment is shown to drive therapeutic resistance in bladder cancer cells with continuous use [166]. Curcumin $(10 \mu \mathrm{mol} / \mathrm{L})$ has been shown to surmount this obstacle by elevating TRAIL and DR5 expressions, and downregulating NF- $\mathrm{kB}$ expression when being co-treated with BCG (106 colony-forming unit (CFU)), thus enhancing extrinsic apoptotic pathways and reversing BCG therapeutic resistance in bladder cancer cells. In vivo studies further elucidated the enhancement of anticancer effects by curcumin and BCG, by inhibiting cell proliferation via the downregulation of cyclin D1 and c-Myc, suppressing angiogenesis via the suppression of VEGF, and boosting apoptosis via the downregulation of Bcl-2 and survivin in xenograft models [138]. Furthermore, the co-treatment of curcumin $(10 \mu \mathrm{M})$ and cisplatin $(10 \mu \mathrm{M})$ induced ROS-mediated apoptosis, which was linked to the overactivation of MAPK/ERK kinase (MEK) and ERK phosphorylation. Moreover, curcumin and cisplatin co-treatment collectively elevated tumor suppressor protein PTEN as well as p53, and downregulated the phosphorylation of STAT3 in 253J-Bv and T24 bladder cancer cells [139].

In acute lymphoblastic leukemia, curcumin $(15 \mu \mathrm{M})$ enhanced the apoptotic effects induced by imatinib $(1 \mu \mathrm{M})$ on SUP-B15 cells through the downregulation of the Akt/mTOR pathway and the upregulation of the Bax/Bcl-2 ratio. Furthermore, the combination treatment also inhibited the expression of breakpoint cluster region protein-acute promyelocytic leukemia (BCR/ABL), in which imatinib monotherapy was unable to do so. In vivo studies verified that the combination of curcumin $(25 \mathrm{mg} / \mathrm{kg})$ and imatinib $(5 \mathrm{mg} / \mathrm{kg})$ reduced the leukemia burden in mice with a decreased expression of BCR/ABL [140]. Further investigations illustrated that curcumin $(10 \mu \mathrm{M})$ with other chemotherapeutic agents, notably imatinib and vincristine, synergistically induced apoptosis via the downregulation of Bcl-2 and anti-angiogenesis effect via the downregulation of VEGF in ALL cells. Besides, combination treatment reversed the NF- $\mathrm{KB}$ activity induced by imatinib and vincristine [141]. Similarly, curcumin $(40 \mu \mathrm{M})$ potentiated the inhibitory effect of thalidomide $(80 \mu \mathrm{M})$ in acute myeloid leukemia cells KG-1 and U937 by downregulating the Bcl-xL expression in apoptosis and repressing STAT3 expression [142]. Apart from that, the combination of natural products, curcumin $(13.47 \mu \mathrm{M})$ and quercetin $(53.89 \mu \mathrm{M})$ synergistically induced apoptosis in chronic myeloid leukemia cells K562 via the downregulation of Bcl-2 and elevated cytochrome $\mathrm{c}$ release to the cytosol. Furthermore, the enhancement of apoptotic effects was evident through the elevation of ROS production and loss of mitochondrial membrane potential [143].

\section{Curcumin Combination Therapy from Bench to Bedside}

Successful preclinical results may not always translate to positive clinical outcomes; hence, clinical investigations in humans are crucial. To date, numerous clinical trials on curcumin combination therapy have been carried out (Table 2), evaluating the safety and tolerability of combined treatments, toxicity profiles, and therapeutic response of patients. These studies provide imperative information for clinicians in designing newly improved robust therapeutic interventions. 
Table 2. Completed clinical trials in curcumin combination therapy.

\begin{tabular}{|c|c|c|c|c|c|c|}
\hline Clinical Trials Identifier & Clinical Trials & Phase & Cancer Type & Treatment Regimens & Objective and Findings & Reference \\
\hline NCT03072992 & $\begin{array}{l}\text { Efficacy and safety of } \\
\text { curcumin in combination } \\
\text { with paclitaxel in } \\
\text { patients with advanced, } \\
\text { metastatic breast cancer: } \\
\text { A comparative, } \\
\text { randomized, } \\
\text { double-blind, } \\
\text { placebo-controlled } \\
\text { clinical trial }\end{array}$ & 2 & Breast cancer & $\begin{array}{l}\text { Curcumin group: } 8 \mathrm{mg} \\
\text { dexamethasone, curcumin } \\
\text { (CUC-01, } 300 \mathrm{mg} \text { solution) and } \\
\text { paclitaxel }\left(80 \mathrm{mg} / \mathrm{m}^{2}\right) \text { injected } \\
\text { intravenously } \\
\text { Placebo group: } 8 \mathrm{mg} \\
\text { dexamethasone, placebo and } \\
\text { paclitaxel }\left(80 \mathrm{mg} / \mathrm{m}^{2}\right) \text { injected } \\
\text { intravenously. }\end{array}$ & $\begin{array}{l}\text { 1. Curcumin group (51\%) had significantly } \\
\text { higher ORR than placebo group }(31 \%) \text {. } \\
\text { The efficacy was maintained for more than } \\
3 \text { months in curcumin group, with higher } \\
\text { RECIST score than baseline. } \\
\text { 3. Median PFS in curcumin group } \\
\text { (27.0 weeks) was } 2.4 \text { weeks longer than } \\
\text { placebo group ( } 24.6 \text { weeks). } \\
\text { TEAEs were lessreported in curcumin } \\
\text { group as compared to placebo group. }\end{array}$ & [167] \\
\hline NA & $\begin{array}{l}\text { Phase I dose escalation } \\
\text { trial of docetaxel plus } \\
\text { curcumin in patients } \\
\text { with advanced and } \\
\text { metastatic breast cancer }\end{array}$ & 1 & Breast cancer & $\begin{array}{l}\text { Docetaxel }\left(100 \mathrm{mg} / \mathrm{m}^{2}\right) \text { as } \\
\text { intravenous infusion on day } 1 \text { of } \\
\text { each } 3 \text { week cycle for } 6 \text { cycles. } \\
\text { Premedicated with } 50 \mathrm{mg} \text { BID of } \\
\text { oral methylprednisolone given } \\
\text { two days before and after } \\
\text { chemotherapy. Six dose levels of } \\
\text { curcumin }(500 \mathrm{mg} / \text { day) for } \\
\text { consecutive } 7 \text { days at each cycle. }\end{array}$ & $\begin{array}{l}\text { 1. Maximal tolerated dose of curcumin was at } \\
8000 \mathrm{mg} / \text { day. } \\
\text { 2. Out of } 8 \text { patients, } 5 \text { patients had PR and } \\
3 \text { patients had SD. } \\
\text { 3. Tumor marker CEA decreased significantly } \\
\text { in patients with PR and SD from the 3rd } \\
\text { cycle of treatment. } \\
\text { 4. VEGF significantly decreased by } 30 \% \\
\text { between baseline and cycle no. } 3 \text {, and by } \\
21 \% \text { between baseline and cycle no. } 6 \text {. }\end{array}$ & [168] \\
\hline NA & $\begin{array}{l}\text { Effect of imatinib } \\
\text { therapy with and } \\
\text { without turmeric } \\
\text { powder on nitric oxide } \\
\text { levels in chronic myeloid } \\
\text { leukemia }\end{array}$ & NA & $\begin{array}{l}\text { Chronic myeloid } \\
\text { leukemia }\end{array}$ & $\begin{array}{l}\text { Curcumin group: imatinib } \\
\text { ( } 400 \mathrm{mg} \text { twice a day) along with } \\
\text { turmeric powder ( } 5 \mathrm{~g} \text { three } \\
\text { times / day dissolved in } 150 \mathrm{~mL} \\
\text { of milk to improve its platability } \\
\text { and absorption) for } 6 \text { weeks. } \\
\text { Imatinib group: imatinib } \\
\text { ( } 400 \mathrm{mg} \text { twice a day for } 6 \\
\text { weeks). }\end{array}$ & $\begin{array}{l}\text { 1. Curcumin group achieved larger } \\
\text { percentage of complete remission, with no } \\
\text { significant difference with imatinib group. } \\
\text { 2urcumin group }(4.06 \pm 1.79 \mu \mathrm{mol} / \mathrm{L}) \text { has } \\
\text { better reduced nitric oxide level than } \\
\text { imatinib group }(14.26 \pm 276 \mu \mathrm{mol} / \mathrm{L}), \text { but } \\
\text { both nitric oxide levels were significantly } \\
\text { reduced as compared to inital nitric oxide } \\
\text { level, } 42.43 \pm 5.79 \mu \mathrm{mol} / \mathrm{L}) \text {. } \\
\text { Limited common side effects were } \\
\text { observed. }\end{array}$ & [169] \\
\hline
\end{tabular}


Table 2. Cont.

\begin{tabular}{|c|c|c|c|c|c|c|}
\hline Clinical Trials Identifier & Clinical Trials & Phase & Cancer Type & Treatment Regimens & Objective and Findings & Reference \\
\hline NCT01490996 & $\begin{array}{l}\text { Curcumin Combined } \\
\text { with FOLFOX } \\
\text { Chemotherapy Is Safe } \\
\text { and Tolerable in Patients } \\
\text { with Metastatic } \\
\text { Colorectal Cancer in a } \\
\text { Randomized Phase IIa } \\
\text { Trial }\end{array}$ & $2 \mathrm{a}$ & Colorectal cancer & $\begin{array}{l}\text { FOLFOX: FOLFOX } \pm \\
\text { bevacizumab. } \\
\text { CUFOX: FOLFOX } \pm \\
\text { bevacizumab plus } 2 \text { g oral } \\
\text { Curcumin C } 3 \text { complex per day. } \\
\text { Chemotherapy was given once } \\
\text { every } 2 \text { weeks for } \leq 12 \text { cycles or } \\
\text { until patient progression, } \\
\text { unacceptable toxicity, death or } \\
\text { withdrawal. }\end{array}$ & $\begin{array}{l}\text { 1. CUFOX was safe and well tolerated. } \\
\text { 2. At } 12 \text { cycle of treatment, ORR reached } \\
\text { 11.1\% and } 53.3 \% \text { for FOLFOX and CUFOX. } \\
\text { 3. Median PFS of CUFOX ( } 320 \text { days) was } \\
\text { higher than FULFOX (171 days). } \\
\text { 4. Median OS of CUFOX (596 days) was } \\
\text { higher than FULFOX (200 days). } \\
\text { 5. CXCL1 in explant culture treated with } \\
\text { CUFOX (180 pg/mL) was lower than } \\
\text { treated with FOLFOX ( } 370 \mathrm{pg} / \mathrm{mL} \text { ). } \\
\text { 6. No significant difference between arms for } \\
\text { QoL or neurotoxicity. }\end{array}$ & [170] \\
\hline NCT01490996 & $\begin{array}{l}\text { Curcumin inhibits cancer } \\
\text { stem cell phenotypes in } \\
\text { ex vivo models of } \\
\text { colorectal liver } \\
\text { metastases, and is } \\
\text { clinically safe and } \\
\text { tolerable in combination } \\
\text { with FOLFOX } \\
\text { chemotherapy }\end{array}$ & 1 & Colorectal cancer & $\begin{array}{l}\text { Daily curcumin dose }(0.5,1 \text { and } \\
2 \text { g) } 7 \text { days prior the } \\
\text { chemotherapy. FOLFOX-based } \\
\text { chemotherapy was } 2 \text {-weekly } \\
\text { cycles given to a maximum of } 12 \\
\text { cycles or until withdrawal from } \\
\text { the trial. }\end{array}$ & $\begin{array}{l}\text { 1. Cur is safe and tolerable up to } 2 \mathrm{~g} \text { daily. } \\
\text { 2. } 91.7 \% \text { patients showed SD or PR to } \\
\text { treatment. } \\
\text { 3. Median PFS was } 34 \text { weeks. }\end{array}$ & [88] \\
\hline NCT01859858 & $\begin{array}{l}\text { Effect of Curcumin on } \\
\text { Dose Limiting Toxicity } \\
\text { and Pharmacokinetics of } \\
\text { Irinotecan in Patients } \\
\text { With Solid Tumors }\end{array}$ & 1 & Colorectal cancer & $\begin{array}{l}\text { Experimental group } 1 \text { : oral } \\
\text { curcumin }(1 \text { to } 4 \mathrm{~g} / \text { day) for } \\
4 \text { days prior to irinotecan }+ \\
200 \mathrm{mg} / \mathrm{m}^{2} \text { irinotecan } \\
\text { intravenous injection, days } 1 \\
\text { and } 15 \\
\text { Experimental group } 2 \text { : maximal } \\
\text { tolerated dose of oral curcumin } \\
\text { as determined from } \\
\text { Experimental group } 1+ \\
200 \mathrm{mg} / \mathrm{m}^{2} \text { irinotecan } \\
\text { intravenous injection, days } 1 \\
\text { and } 15\end{array}$ & $\begin{array}{l}\text { 1. To determine the safety, pharmacokinetics } \\
\text { and effectiveness of irinotecan when given } \\
\text { in combination with curcumin in patients } \\
\text { with metastatic colorectal cancer. } \\
\text { 2. To better understand the interaction } \\
\text { between curcumin and irinotecan by } \\
\text { measuring levels of irinotecan in blood } \\
\text { when a patient also takes curcumin. } \\
\text { 3. Information will result in improved dosing } \\
\text { guidelines and lead to more effective } \\
\text { treatment with lesser toxicity. }\end{array}$ & NA \\
\hline
\end{tabular}


Table 2. Cont

\begin{tabular}{|c|c|c|c|c|c|c|}
\hline Clinical Trials Identifier & Clinical Trials & Phase & Cancer Type & Treatment Regimens & Objective and Findings & Reference \\
\hline NCT00192842 & $\begin{array}{l}\text { Curcumin and } \\
\text { Gemcitabine in Patients } \\
\text { With Advanced } \\
\text { Pancreatic Cancer }\end{array}$ & 2 & Pancreatic Cancer & $\begin{array}{l}\text { A total of } 8 \mathrm{~g} \text { of curcumin } \\
\text { (Sabinsa Corporation) by mouth } \\
\text { daily concurrently with } \\
\text { gemcitabine }\left(1000 \mathrm{mg} / \mathrm{m}^{2}\right) \\
\text { intravenously weekly for } 3 \text { of } \\
4 \text { weeks. }\end{array}$ & $\begin{array}{l}\text { 1. Some gastrointestinal toxicity such as } \\
\text { abdominal fullness and pain were } \\
\text { observed appeared in } 7 \text { patients. } \\
\text { 2. Local control rate of } 45.5 \% \text { was recorded, } \\
\text { with } 9.1 \% \text { of patients having partial } \\
\text { response for } 7 \text { months; } 36.4 \% \text { of patients } \\
\text { had stable disease lasting for } 2,3,6 \text {, and } \\
12 \text { months; } 54.5 \% \text { of patients had tumor } \\
\text { progression. } \\
\text { 3. The median TTP was } 2.5 \text { months. } \\
\text { 4. The median OS was } 5 \text { months. }\end{array}$ & [171] \\
\hline NA & $\begin{array}{l}\text { Phytosome complex of } \\
\text { curcumin as } \\
\text { complementary therapy } \\
\text { of advanced pancreatic } \\
\text { cancer improves safety } \\
\text { and efficacy of } \\
\text { gemcitabine: Results of a } \\
\text { prospective phase II trial }\end{array}$ & 2 & Pancreatic Cancer & $\begin{array}{l}\text { Meriva (curcumin) } 2000 \mathrm{mg} / \mathrm{die} \\
\text { continuously ( } 4 \text { capsules, each } \\
500 \mathrm{mg} \text {, every day) and } \\
\text { gemcitabine }\left(10 \mathrm{mg} / \mathrm{m}^{2} / \mathrm{min}\right. \\
\text { infused over } 100 \mathrm{~min} \text { and } \\
\text { diluted in } 500 \mathrm{~mL} \text { of normal } \\
\text { saline on days } 1,8,15 \mathrm{in} \text { the } \\
\text { dose-intense schedule. Each } \\
\text { cycle was given every } 28 \text { days. }\end{array}$ & $\begin{array}{l}\text { 1. A percentage of } 27.3 \% \text { of RR and } 34.1 \% \text { of } \\
\text { SD, totalizing a disease control rate of } \\
61.4 \% \text {. } \\
\text { 2. Median PFS and OS were } 8.4 \text { and } 10.2 \\
\text { months, respectively. } \\
\text { 3. Curcumin is safe and efficiently translates } \\
\text { in a good RR in first line therapy of } \\
\text { advanced pancreatic cancer. }\end{array}$ & [172] \\
\hline UMIN-ID 000001386 & $\begin{array}{l}\text { A phase I/II study of } \\
\text { gemcitabine-based } \\
\text { chemotherapy plus } \\
\text { curcumin for patients } \\
\text { with } \\
\text { gemcitabine-resistant } \\
\text { pancreatic cancer }\end{array}$ & 1 and 2 & Pancreatic Cancer & $\begin{array}{l}\text { Curcumin group: oral curcumin } \\
(8 \mathrm{~g})+\text { intravenous } \\
\text { administration of gemcitabine at } \\
\text { a dose of } 1000 \mathrm{mg} / \mathrm{m}^{2} \text { on days } 1 \\
\text { and } 8 \text { and } 60 \mathrm{mg} / \mathrm{m}^{2} \text { of } S-1 \\
\text { orally for } 14 \text { consecutive days } \\
\text { every } 3 \text { weeks. } \\
\text { Experimental group: } \\
\text { gemcitabine monotherapy }\end{array}$ & $\begin{array}{l}\text { 1. Advanced pancreatic cancer patients } \\
\text { completed first cycle treatment for phase } 1 \\
\text { study without any dose limited toxicity at } \\
8 \mathrm{~g} / \text { day. } \\
\text { 2. Median OS time was } 161 \text { days and } 1 \text { year } \\
\text { survival rate was } 19 \% \text {. } \\
\text { 3. Oral curcumin with } 8 \mathrm{~g} \text { was safe and } \\
\text { feasible in patients with advanced } \\
\text { pancreatic cancer. }\end{array}$ & [173] \\
\hline
\end{tabular}


Table 2. Cont.

\begin{tabular}{|c|c|c|c|c|c|c|}
\hline Clinical Trials Identifier & Clinical Trials & Phase & Cancer Type & Treatment Regimens & Objective and Findings & Reference \\
\hline NA & $\begin{array}{l}\text { Phase II study of } \\
\text { gemcitabine and } \\
\text { curcumin as first line } \\
\text { treatment for locally } \\
\text { advanced or metastatic } \\
\text { pancreatic cancer: } \\
\text { preliminary data }\end{array}$ & 2 & Pancreatic Cancer & $\begin{array}{l}\text { Gemcitabine }(1000 \mathrm{mg} / \mathrm{mq} \text { in } \\
100 \mathrm{~min} \text { on day } 1,8,15 \text { every } \\
28 \text { days) and curcumin } \\
\text { ( } 2000 \mathrm{mg} / \text { day, continuously) } \\
\text { until progression or } \\
\text { unacceptable toxicities or } \\
\text { patients refusal. }\end{array}$ & $\begin{array}{l}\text { 1. Overall RR was } 28.2 \% \text { and SD was } 33.3 \% \text { of } \\
\text { cases, totalizing a disease control rate of } \\
61.5 \% \text {. } \\
\text { 2. Supplementation of curcumin to } \\
\text { gemcitabine was safe and well tolerated. }\end{array}$ & [174] \\
\hline NCT01012141 & $\begin{array}{l}\text { The New Combination } \\
\text { Docetaxel, Prednisone } \\
\text { and Curcumin in } \\
\text { Patients with } \\
\text { Castration-Resistant } \\
\text { Prostate Cancer: A Pilot } \\
\text { Phase II Study }\end{array}$ & 2 & Prostate Cancer & $\begin{array}{l}\text { Curcumin } 6000 \mathrm{mg} \text { per day (12 } \\
\text { capsules with } 500 \mathrm{mg} \text { in each } \\
\text { capsule) for } 7 \text { consecutive days } \\
\text { in each cycle + prednisone } 5 \mathrm{mg} \\
\text { or prednisoline orally twice } \\
\text { daily on day } 1+\text { docetaxel, } 75 \\
\mathrm{mg} / \mathrm{m}^{2} \text { delivered as a } 1 \mathrm{~h} \\
\text { intravenous infusion on day } 1 \\
\text { every } 21 \text { days for } 6 \text { cycles, with } \\
\text { pre-medication with } \\
\text { dexamethasone, } 8 \mathrm{mg} \text { given } 12 \text {, } \\
3 \text { and } 1 \mathrm{~h} \text { before docetaxel } \\
\text { infusion. }\end{array}$ & $\begin{array}{l}\text { 1. A total of } 34 \% \text { of patients had stable PSA } \\
\text { levels and } 7 \% \text { presented with PSA } \\
\text { progression. } \\
\text { A total of } 40 \% \text { had partial response, } 60 \% \\
\text { had stable disease; all patients benefit from } \\
\text { the combination study. } \\
\text { 3. Median TTP of PSA was } 5.8 \text { months. } \\
\text { 4. No patients withdrew due to toxicity. No } \\
\text { toxic effect was attributed to curcumin. } \\
\text { 5. OS was correlated with NE (NSE and CgA) } \\
\text { markers. }\end{array}$ & [175] \\
\hline NCT03211104 & $\begin{array}{l}\text { A randomized, } \\
\text { double-blind, } \\
\text { placebo-controlled trial } \\
\text { to evaluate the role of } \\
\text { curcumin in prostate } \\
\text { cancer patients with } \\
\text { intermittent androgen } \\
\text { deprivation }\end{array}$ & NA & Prostate Cancer & $\begin{array}{l}\text { Curcumin group: taking } \\
\text { curcumin } 3 \text { times a day } \\
\text { ( } 1440 \mathrm{mg} \text { /day) for } 6 \text { months } \\
\text { from the beginning of androgen } \\
\text { deprivation therapy withdrawal. } \\
\text { Placebo group: taking placebo } \\
\text { for } 6 \text { months from the beginning } \\
\text { of androgen deprivation therapy } \\
\text { withdrawal. }\end{array}$ & $\begin{array}{l}\text { 1. The median off-treatment duration was } \\
\text { 16.3 months and } 18.5 \text { months in the } \\
\text { curcumin group and placebo group, } \\
\text { respectively. } \\
\text { 2. The proportion of patients with PSA } \\
\text { progression during the active curcumin } \\
\text { treatment period ( } 6 \text { months) was } \\
\text { significantly lower in the curcumin group } \\
\text { than the placebo group. } \\
\text { 3. Curcumin was well tolerated and safe. }\end{array}$ & [176] \\
\hline
\end{tabular}


Table 2. Cont.

\begin{tabular}{|c|c|c|c|c|c|c|}
\hline Clinical Trials Identifier & Clinical Trials & Phase & Cancer Type & Treatment Regimens & Objective and Findings & Reference \\
\hline NCT01917890 & $\begin{array}{l}\text { Effect of Curcumin } \\
\text { Supplementation During } \\
\text { Radiotherapy on } \\
\text { Oxidative Status of } \\
\text { Patients with Prostate } \\
\text { Cancer: A Double } \\
\text { Blinded, Randomized, } \\
\text { Placebo-Controlled } \\
\text { Study }\end{array}$ & NA & Prostate Cancer & $\begin{array}{l}\text { Patients received curcumin }(3 \mathrm{~g}) \\
\text { or placebo since } 1 \text { week before } \\
\text { onset of radiotherapy until } \\
\text { completion of their radiotherapy. } \\
\text { External beam radiotherapy was } \\
\text { given as daily fraction of } 2 \mathrm{~Gy} \text { to } \\
\text { achieve a total dose of } 74 \mathrm{~Gy} \\
\text { ( } 5 \text { times a week for about } 8 \\
\text { weeks). }\end{array}$ & $\begin{array}{l}\text { 1. Curcumin supplementation did not cause } \\
\text { any side effects. } \\
\text { 2. In curcumin group, plasma total } \\
\text { antioxidant capacity was significantly } \\
\text { increased, and the activity of superoxide } \\
\text { dismutase decreased after radiotherapy as } \\
\text { compared to baseline level and placebo } \\
\text { group. }\end{array}$ & [177] \\
\hline
\end{tabular}

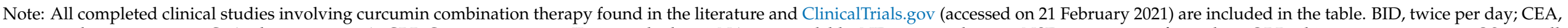

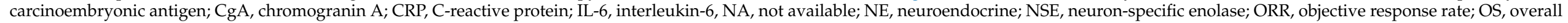

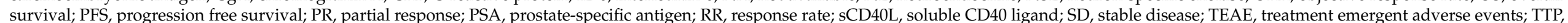
time to progression; VEGF, vascular endothelial growth factor. 
Curcumin combination therapy was proven to be safe and tolerable in the clinical trials of breast cancers [167], chronic myeloid leukemia [169], colorectal cancer [88,170], pancreatic cancer $[172,174]$ and prostate cancers $[176,177]$. Furthermore, patients experienced lesser toxicity effects under the curcumin combination therapy with an improved quality of life. In a phase II placebo-controlled clinical trial, metastatic breast cancer patients encountered lesser treatment-emergent adverse events (TEAEs) under the treatment of paclitaxel $\left(80 \mathrm{mg} / \mathrm{m}^{2}\right)$ and curcumin (300 $\mathrm{mg}$ solution) as compared to the patients receiving the placebo [167]. Moreover, the safety and tolerability of curcumin (up to $2 \mathrm{~g}$ ) was well documented when co-administered with folinic acid, 5-FU and oxaliplatin (FOLFOX) chemotherapy to metastatic colorectal cancer patients [88,170]. In another randomized, double-blinded and placebo-controlled study, prostate cancer patients who received curcumin $(1440 \mathrm{mg} /$ day) until the completion of ADT did not experience any serious adverse effects [176]. Similarly, the supplementation of curcumin ( $3 \mathrm{~g}$ ) did not result in any adverse effects to the prostate cancer patients throughout the radiotherapy [177]. These studies present the evidence of the safety and tolerability of curcumin when co-administered with conventional therapy.

In assessing the treatment response of curcumin combination therapy, a phase I doseescalation clinical trial showed that the maximal tolerated dose of curcumin $(8000 \mathrm{mg} /$ day) co-treated with docetaxel $\left(100 \mathrm{mg} / \mathrm{m}^{2}\right)$ recorded $5 / 8$ patients had partial response (PR) and $3 / 8$ patients had stable disease (SD), with a significant decrease in the tumor marker carcinoembryonic antigen (CEA) and VEGF biomarkers of metastatic breast cancer [168]. Imatinib (400 $\mathrm{mg}$ twice per day) supplemented with turmeric powder ( $5 \mathrm{~g}$ three times/day dissolved in $150 \mathrm{~mL}$ of milk) achieved a higher complete remission in chronic myeloid leukemia patients. Additionally, curcumin combination treatment caused a better reduction in the nitric oxide level in patients, when compared with imatinib monotherapy [169].

In terms of the overall response rate (ORR), advanced breast cancer patients receiving curcumin (300 mg solution) and paclitaxel $\left(80 \mathrm{mg} / \mathrm{m}^{2}\right)$ experienced significantly higher ORR than patients receiving the placebo [167]. The co-administration of curcumin (2 g) into FOLFOX-based chemotherapy showed a higher ORR (53.3\%), with a longer median progression-free survival (PFS) and overall survival (OS), as compared to the ORR of FOLFOX-based monotherapy (11.1\%) in metastatic colorectal cancer patients [170]. Another clinical trial of colorectal cancer patients receiving a daily dose of curcumin $(2 \mathrm{~g})$ with FOLFOX chemotherapy showed $91.7 \%$ ORR, with a median PFS of 34 weeks [88]. In a phase II study on the castration-resistant prostate cancer patients treated with docetaxel $\left(75 \mathrm{mg} / \mathrm{m}^{2}\right)$, prednisone $(5 \mathrm{mg})$ and curcumin $(6000 \mathrm{mg} /$ day), the ORR was $100 \%$, with $40 \%$ having PR and $60 \%$ having SD, with a median time to progression of prostate-specific antigen (PSA) of 5.8 months [175]. Similarly, prostate cancer patients who received curcumin (1440 mg/day) in ADT had significantly lower PSA progression than patients who received ADT alone only [176]. There was an increase in plasma antioxidant capacity in prostate cancer patients who received curcumin $(3 \mathrm{~g})$ throughout the radiotherapy [177]. These studies demonstrated that curcumin showed treatment response when co-administrated with conventional cancer therapies.

Despite the remarkable outcomes discussed above, reports on curcumin supplementation exhibiting modest treatment response in pancreatic cancer patients have been found. In a phase II study with advanced pancreatic cancer patients treated with curcumin $(8 \mathrm{~g})$ and gemcitabine $\left(1000 \mathrm{mg} / \mathrm{m}^{2}\right)$, the ORR was reported to be $45.5 \%$, while $54.5 \%$ of the patients had tumor progression. Besides, some patients experienced gastrointestinal toxicity, such as abdominal fullness and pain [171]. In another phase II trial, advanced pancreatic cancer patients receiving curcumin $(2000 \mathrm{mg} / \mathrm{die})$ co-treated with gemcitabine $\left(10 \mathrm{mg} / \mathrm{m}^{2}\right.$ or $1000 \mathrm{mg} / \mathrm{mq}$ ) had about $61 \%$ of ORR; albeit, curcumin was safe and tolerable [172,174]. In another phase I/II study, gemcitabine-resistant pancreatic cancer patients who received curcumin $(8 \mathrm{~g})$ and gemcitabine $\left(1000 \mathrm{mg} / \mathrm{m}^{2}\right)$ experienced a poor 1-year survival rate [173]. 
Current findings confirm the effectiveness of curcumin combination treatment in breast cancer, colorectal cancer, and prostate cancer, and less significant effectiveness in pancreatic cancer. Nevertheless, a few trials on pancreatic cancers are still ongoing, with no results available to date. Hence, the conclusion can only be drawn when more data are available. At this point of time, the evidence suggests that certain cancers and/or certain cell lines are more responsive to curcumin combination anticancer treatment. This is not surprising given the different characteristics of the cancer cells, the complexities of molecular pathways involved and the variety of treatment cocktails used. Numerous clinical studies on curcumin co-administration with various conventional cancer therapy are still in progress at the time of writing (Table 3).

Table 3. On-going clinical trial with curcumin combined therapy.

\begin{tabular}{|c|c|c|c|c|c|c|}
\hline $\begin{array}{l}\text { Clinical Trial } \\
\text { Number }\end{array}$ & Title & Phase & Cancer Type & Treatment Regimens & & Research Objective \\
\hline NCT02724202 & $\begin{array}{l}\text { Curcumin in } \\
\text { Combination With } \\
\text { 5FU for Colon Cancer }\end{array}$ & 1 & Colon cancer & $\begin{array}{l}\text { All subjects receive } \\
\text { induction oral } \\
\text { curcumin } 500 \text { mg twice } \\
\text { per day for } 2 \text { weeks. } \\
\text { Patients will continue } \\
\text { on curcumin at same } \\
\text { dose for an additional } \\
6 \text { weeks while being } \\
\text { treated with } 3 \text { cycles of } \\
\text { 5-FU. }\end{array}$ & 2. & $\begin{array}{l}\text { Confirm clinical safety and } \\
\text { identify clinical response rate in } \\
\text { chemorefractory CRC patients. } \\
\text { To determine whether curcumin } \\
\text { administration induces } \\
\text { systemic alterations in } \\
\text { inflammatory and epigenetic } \\
\text { biomarkers. } \\
\text { To correlate altered biomarker } \\
\text { findings with clinical response } \\
\text { according to RECIST V1.1 and } \\
\text { survival criteria. }\end{array}$ \\
\hline NCT02439385 & $\begin{array}{l}\text { Avastin/FOLFIRI in } \\
\text { Combination With } \\
\text { Curcumin in } \\
\text { Colorectal Cancer } \\
\text { Patients With } \\
\text { Unresectable } \\
\text { Metastasis }\end{array}$ & 2 & Colorectal cancer & $\begin{array}{l}\text { Patients receive first } \\
\text { line Avastin/FOLFIRI } \\
\text { in combination with } \\
\text { dietary } \\
\text { supplementation of } \\
\text { nanostructured lipid } \\
\text { curcumin particle } \\
100 \mathrm{mg} \text { po bid daily. }\end{array}$ & $\begin{array}{l}1 . \\
2 .\end{array}$ & $\begin{array}{l}\text { To evaluate PFS of CRC } \\
\text { patients. } \\
\text { To evaluate overall survival } \\
\text { rate, overall response rate, } \\
\text { safety, QoL and fatigue scaling. }\end{array}$ \\
\hline NCT01948661 & $\begin{array}{l}\text { Anthocyanin Extract } \\
\text { and Phospholipid } \\
\text { Curcumin in } \\
\text { Colorectal Adenoma } \\
\text { (MIRACOL) }\end{array}$ & 2 & Colorectal cancer & $\begin{array}{l}\text { Group A: Mirtoselect } \\
500 \mathrm{mg} \text { tablet, } 1000 \mathrm{mg} \\
\text { (two oral tablets) per } \\
\text { day and Meriva }^{\circledR} \\
\text { (Curcumin), } 500 \mathrm{mg} \\
\text { tablet, } 1000 \mathrm{mg} \text { (two } \\
\text { oral tablets) per day for } \\
28 \text { days. } \\
\text { Group B: placebo A + } \\
\text { placebo B per day for } \\
\text { four weeks. }\end{array}$ & 1. & $\begin{array}{l}\text { To measure the change of } \\
\text { immunohistochemical } \\
\text { expression of } \beta \text {-catenin in } \\
\text { normal and adenomatous } \\
\text { colonic tissue. } \\
\text { To measure the change of } \\
\text { immunohistochemical } \\
\text { expression of NF- } \mathrm{B}, \mathrm{Ki}-67 \\
\text { Labeling Index and p53 in } \\
\text { normal and adenomatous } \\
\text { mucosa. }\end{array}$ \\
\hline NCT02321293 & $\begin{array}{l}\text { A Open-label } \\
\text { Prospective Cohort } \\
\text { Trial of Curcumin } \\
\text { Plus Tyrosine Kinase } \\
\text { Inhibitors (TKI) for } \\
\text { EGFR -Mutant } \\
\text { Advanced NSCLC } \\
\text { (CURCUMIN) }\end{array}$ & 1 & Lung cancer & $\begin{array}{l}\text { CurcuVIVA (NPN } \\
80027414 \text { ) at a single } \\
\text { dose of } 80 \mathrm{mg} \text { PO daily } \\
\text { in conjunction with } \\
\text { gefitinib } \\
250 \mathrm{mg} / \text { erlotinib } \\
150 \mathrm{mg} \text { given in a } \\
\text { capsule form once } \\
\text { daily. }\end{array}$ & $\begin{array}{l}2 . \\
3 .\end{array}$ & $\begin{array}{l}\text { To determine the safety and } \\
\text { feasibility of curcumin in } \\
\text { chemotherapy. } \\
\text { To assess changes in } \\
\text { health-related QoL. } \\
\text { To evaluate anti-inflammatory } \\
\text { properties via CRP measure. }\end{array}$ \\
\hline
\end{tabular}


Table 3. Cont.

\begin{tabular}{|c|c|c|c|c|c|}
\hline $\begin{array}{l}\text { Clinical Trial } \\
\text { Number }\end{array}$ & Title & Phase & Cancer Type & Treatment Regimens & Research Objective \\
\hline NCT03598309 & $\begin{array}{l}\text { Phase II Trial to } \\
\text { Modulate } \\
\text { Intermediate } \\
\text { Endpoint Biomarkers } \\
\text { in Former Smokers }\end{array}$ & 2 & Lung cancer & $\begin{array}{l}\text { Group A: } 4 \text { g Lovaza }{ }^{\circledR} \text {, } \\
2 \text { g BID. } 8000 \text { mgs CUR } \\
\text { Curcumin C3 complex }{ }^{\circledR} \\
\text { tablets, } 4000 \text { mgs BID. } \\
\text { Group B: } 2 \text { g Lovaza }{ }^{\circledR}, \\
1 \text { g BID. } 4000 \text { mgs CUR } \\
\text { Curcumin C } 3 \text { complex }{ }^{\circledR} \\
\text { tablets, } 2000 \text { mgs BID. } \\
\text { Group C: Two } \\
\text { matching placebo } \\
\text { capsules BID. }\end{array}$ & $\begin{array}{l}\text { To determine the safety and } \\
\text { tolerability of treatment. } \\
\text { 2. To determine the mean change } \\
\text { in bronchial nodule size. } \\
\text { 3. To study the rate of adherence } \\
\text { per study arm. } \\
\text { 4. To evaluate the rate of } \\
\text { treatment-related adverse } \\
\text { events. }\end{array}$ \\
\hline
\end{tabular}

Phase III Trial of

Gemcitabine,

Curcumin and

NCT00486460

With Advance or

Inoperable Pancreatic

Cancer
Gemcitabine +

Curcumin and/or

Celecoxib
1. To evaluate gemcitabine in combination with curcumin and celecoxib for patients with pancreatic cancer.
Testing the

Synergism of

Phytonutrients,

NCT04403568

cumin and
Cancer

Ursolic Acid, to

Target Molecular

Pathways in the

Prostate
Nanocurcumin for

NCT02724618

\section{Prostate Cancer}

Patients Undergoing

Radiotherapy (RT)

\section{2}

Prostate Cancer
Cohort 1: Ursolic Acid (150 mg) BID.

Cohort 2: Cur (600 mg) BID.

Cohort 3: Ursolic Acid $(150 \mathrm{mg})+$ Cur (600 mg) BID.

These administrations are subjected to the patients who are scheduled to undergo radical prostatectomy.
1. To evaluate the bioavailability and safety of treatment.

2. To confirm the presence and levels of ursolic acids and curcumin metabolites in the target organ

3. To validate the appropriate mechanisms of effect.

4. To determine $\mathrm{p} 65 \mathrm{NF}-\mathrm{kB}$ level before and after prostatectomy via immunohistochemistry.
Experimental group:

$120 \mathrm{mg} / \mathrm{d}$ oral

nanocurcumin (3

capsules of

SinaCurcumin ${ }^{\circledR} 40$ per

day) 3 days before and

during radiotherapy +

external beam radiation

therapy

Placebo comparator:

placebo (3 placebo

capsules of

SinaCurcumin ${ }^{\circledR} 40$ per day), 3 days before and during radiotherapy + external beam radiation therapy.

\begin{tabular}{|c|c|c|c|c|c|c|}
\hline NCT04731844 & $\begin{array}{l}\text { Curcumin and } \\
\text { Piperine in Patients } \\
\text { on Surveillance for } \\
\text { Monoclonal } \\
\text { Gammopathy, } \\
\text { Smoldering Myeloma } \\
\text { or Prostate Cancer }\end{array}$ & 2 & $\begin{array}{l}\text { Prostate Cancer, } \\
\text { Multiple } \\
\text { Myeloma, } \\
\text { Smoldering } \\
\text { Multiple } \\
\text { Myeloma, } \\
\text { Monoclonal } \\
\text { Gammopathy of } \\
\text { Undetermined } \\
\text { Significance }\end{array}$ & $\begin{array}{l}\text { Experimental group: } \\
\text { curcumin plus piperine } \\
\text { at a dose of } 4 \mathrm{~g} / 5 \mathrm{mg} \\
\text { orally BID for } 12 \\
\text { months. }\end{array}$ & 2. & $\begin{array}{l}\text { To determine the response rate } \\
\text { of curcumin and piperine } \\
\text { supplementation in patients. } \\
\text { To determine the PFS. }\end{array}$ \\
\hline
\end{tabular}

Note: All on-going clinical studies involving curcumin combination therapy found in the literature and ClinicalTrials.gov (accessed on 21 February 2021) are included in the table. BID, twice a day CRC, colorectal cancer; CRP, C-reactive protein; PFS, progression free survival; QoL, quality of life. 


\section{Research Gap and Future Directions}

A large body of research demonstrated the role of curcumin in augmenting anticancer effects via combination therapy. Although the majority of studies reported positive therapeutic outcomes, some opposing results were observed in which the curcumin did not elicit a synergistic effect with combination therapy in various dosages $[67,112,133]$. The inconsistencies among the results warrant further investigations. To obtain robust methodology and ensure accurate results, careful considerations in the study planning is vital in both preclinical and clinical investigations.

In some studies, in vitro results were used to draw the conclusion without validation from in vivo findings. Care should be taken in interpreting these results, as in vitro findings can sometimes be a poor predictor of in vivo outcomes. Moreover, various factors, including cell-immune regulations in microenvironment and toxicity profiling, remain elusive without the integration of in vivo studies [178]. Therefore, in vivo investigations are necessary to validate the in vitro results before proceeding to human studies [41]. This means more laborious works are needed to be put in place to conduct the studies. However, it does more good than harm in the long run, with more solid preclinical evidence out there for progression into clinical trials.

Besides inducing apoptosis, curcumin is a potent regulator of autophagy in cancers. As a stress-coping mechanism, autophagy eliminates the cancer cells in the early stage of cancers. However, autophagy has also been shown to promote the survival of cancer cells by mitigating nutrient deprivation and hypoxia stress in the advanced stage of cancer $[179,180]$. There have been controversial opinions on whether curcuminmediated autophagy modulates pro-survival or pro-death mechanisms in cancer cells [181]. The combination treatment of curcumin $(5 \mu \mathrm{M})$ and berberine $(25 \mu \mathrm{M})$ synergistically induce autophagy-related cell death in MDA-MB-231 and MCF7 breast cancer cells via the increased activation of c-Jun N-terminal kinase (JNK) signalling [76]. Similarly, the enhancement of H157 and H1299 lung cancer cell death by the combination of curcumin and gefitinib was autophagy-dependent [95]. However, Kantara et al. (2014) demonstrated that curcumin promoted autophagic cell survival of doublecortin-like kinase 1 (DCLK1) positive-CSCs in colon cancer. The ablation of DCLK1 in colon cancer CSC only restored the cell death-promoting effects mediated by curcumin, highlighting that curcumin-mediated autophagy is dependent on the expression of DCLK1 [182]. Hence, curcumin-mediated autophagy can be a double-edged sword, and this depends on cancer types and targeted signalling pathways $[183,184]$. This presents room for investigation to further explore the crosstalk between apoptosis and autophagy mediated by curcumin combination treatment.

Albeit curcumin is safe and tolerable [7], and the toxicity issue, especially in persistent consumption, is often overlooked due to the lack of long-term clinical studies [185]. Moreover, increasing the dosage of curcumin has been shown to negatively regulate the anti-oxidant effects by inducing DNA damage and degrading p53 proteins, leading to potential carcinogenic effects $[186,187]$. In vivo studies demonstrated that curcumin is an active iron chelator. This implicates that the constitutive consumption of iron will impair the iron homeostasis in patients who have a suboptimal level of iron [188]. Several in vitro studies also illustrated that curcumin and other chemotherapeutic agents exhibited antagonistic effects, reversing the anticancer effects by restricting apoptosis and cytotoxicity potential in cancer cells [189]. For instance, the curcumin dietary supplementation antagonized the cyclophosphamide-induced tumor suppression in BT474 xenograft mouse models via the downregulation of JNK activities [190]. Besides, the co-treatment of curcumin and etoposide had an antagonistic effect in MC7 breast cancer cells, HepG2 liver cancer cells, HCT116 colon cancer cells and HeLa cervical cancer cells. Cell cycle analysis revealed that this co-treatment limited the cell death of cancer cells by restricting the cells entering $M$ phase [191]. These issues warrant the need for stringent dose-response evaluation, attentive choices of drug combination, and long-term clinical follow up to determine the optimum dose of curcumin in maximizing therapeutic response without instigating any toxicity events. 
Due to the heterogeneity of cancer and disparity in the genetic makeup of cancer patients, there could be discrepancies in the therapeutic efficacy of curcumin combination therapy among cancer patients. To address this issue, precision medicine can be applied to understand the underlying cause of cancer in a patient. This can be achieved through a multitude of drug screenings using curcumin as a main therapeutic agent combined with an array of conventional therapeutic agents. In addition to that, gene sequencing technology can be a useful tool in identifying tumor-associated vulnerabilities as therapeutic targets in cancer patients. Once a specific gene mutation is confirmed, the anticancer treatment can then be designed and tailored for the patient. Undoubtly, these interventions will foster the developments of highly effective curcumin combination therapy regimens that will target the precise cause of disease in an individual patient [192,193].

It is noteworthy that in most of the clinical trials, a remarkably high dose of curcumin was used. Curcumin is notorious for its hydrophobic nature, thereby restricting its pharmacokinetic potential by having poor aqueous solubility, poor bioavailability, and rapid systemic elimination from the body [194]. These characteristics have impeded its ability to reach the target area. As a result, a high dose of curcumin has to be administered to account for these shortcomings, in order to maintain the effective plasma concentration in the blood. In reality, a high dose of curcumin might be impractical in a clinical setting, as it necessitates the administration of several large tablets/capsules for a single dose. Moreover, the gastrointestinal side effect observed in one of the clinical trials signifies the potential irritant effect of large dose of curcumin. Hence, room for improvement exists in delivering curcumin as combination therapy for cancer patients. Specifically, this issue should be addressed before this treatment option is made available to patients. In this regard, refining the formulation of curcumin appears to be an important step. The improved formulation of curcumin should address the poor bioavailability and rapid degradation issues. The nanoformulation of curcumin is one of the options to be used, as these have been shown to be able to increase drug payload in a single dose, at the same time allowing the flexibility of modifying the nanoformulation according to needs. With the proper choice of excipients, the stability of curcumin could also be improved, where the nanomaterials could protect the compound from degradation. In fact, several reports illustrated that the application of nanoformulation in curcumin combination therapy has successfully demonstrated the enhanced aqueous solubility for better delivery [195], reversing multidrug resistance [108] and ensuring the distinctive biodistribution of therapeutic agents $[107,196]$. On the other hand, the nanoformulation of curcumin could also be designed to target a specific site of the body, to deliver an even higher dose of the compound to the site of action, instead of distributing to other organs. One of the examples is curcumin nanoparticles with a mucoadhesive effect for colorectal cancer [196-198]. It is expected that the nanoparticles would have prolonged contact time with the colon due to mucoadhesion between the nanoparticles and the colonic mucin. This will allow a greater amount of curcumin to be released on-site and act on the cancer cells. Utilizing the same concept, a nanoformulation containing both curcumin and the chemotherapeutic agent can then be engineered for such delivery for better treatment outcomes. It would be interesting to observe the outcome of the ongoing clinical trials on the combination chemotherapy with curcumin nanoformulations.

\section{Conclusions}

The search for an effective cancer therapeutic strategy remains a great challenge for the scientific community due to various side effects, general cytotoxicity to cancer and normal cells, and the development of therapeutic resistance, which often lead to therapeutic failure. Combination therapy presents a good option to alleviate the tumor burdens by lowering toxicity and simultaneously targeting multiple mechanisms that modulate tumor development, without harming the healthy cells.

Curcumin holds a great promise in the development of combination therapy, which is frequently paired with conventional chemotherapeutic drugs as well as other natural 
compounds. An enormous body of preclinical and clinical evidence had entailed the potential of curcumin in preventing the exacerbation of cancer development by modulating multiple signalling pathways when combined with other therapeutic agents. Apart from diminishing cell survival and elevating cancer cell death, curcumin combination therapy has a robust effect in alleviating the hallmarks of cancer, such as metastasis and angiogenesis progression. The combined treatment of curcumin with other conventional therapy could overcome the pitfalls contributed by persistent conventional treatments and the genetic constitution of cancer cells, resulting in the improvement of therapeutic outcome. However, the poor pharmacokinetic issues of curcumin need to be addressed first. This could be resolved through the application of appropriate drug delivery systems, such as nanoformulation, that could effectively improve the delivery of curcumin to the target sites. The controversy surrounding the use of curcumin, such as its antagonistic effect, autophagy modulation, and potential toxicity associated with its long term use, warrants more studies and long-term clinical monitoring. With the continuous exploration of curcumin combination therapy and a deep understanding of its modulation in anticancer mechanisms, curcumin combination therapy holds great promise as a new therapeutic approach in combating cancer, especially in cancer patients irresponsive to single conventional chemotherapy. It is noteworthy that deep molecular profiling is essential for understanding the tumor-associated biomarkers that are crucially influenced by the action of curcumin, thereby shaping the future combined therapeutic strategies that eventually will translate into better oncologic outcome.

Author Contributions: Conceptualization, writing-review and editing, supervision, L.-H.C.; resources, data curation, writing-original draft preparation, W.-Y.K.; review and supervision, S.C.N.; review and critical insights, B.-H.G., L.-H.L., T.-T.H. All authors have read and agreed to the published version of the manuscript.

Funding: This research received no external funding.

Conflicts of Interest: The authors declare no conflict of interest.

\section{References}

1. Sung, H.; Ferlay, J.; Siegel, R.L.; Laversanne, M.; Soerjomataram, I.; Jemal, A.; Bray, F. Global cancer statistics 2020: GLO-BOCAN estimates of incidence and mortality worldwide for 36 cancers in 185 countries. CA Cancer J. Clin. 2021, 71, 209-249. [CrossRef] [PubMed]

2. Tan, B.L.; Norhaizan, M.E. Curcumin Combination Chemotherapy: The Implication and Efficacy in Cancer. Molecules 2019, 24, 2527. [CrossRef]

3. Feitelson, M.A.; Arzumanyan, A.; Kulathinal, R.J.; Blain, S.W.; Holcombe, R.F.; Mahajna, J.; Marino, M.; Chantar, M.L.M.; Nawroth, R.; Sanchez-Garcia, I.; et al. Sustained proliferation in cancer: Mechanisms and novel therapeutic targets. Semin. Cancer Biol. 2015, 35, S25-S54. [CrossRef] [PubMed]

4. Mokhtari, R.B.; Homayouni, T.S.; Baluch, N.; Morgatskaya, E.; Kumar, S.; Das, B.; Yeger, H. Combination therapy in combating cancer. Oncotarget 2017, 8, 38022-38043. [CrossRef] [PubMed]

5. Hanahan, D.; Bergers, G.; Bergsland, E. Less is more, regularly: Metronomic dosing of cytotoxic drugs can target tumor angiogenesis in mice. J. Clin. Investig. 2000, 105, 1045-1047. [CrossRef]

6. Peng, M.; Xiao, D.; Bu, Y.; Long, J.; Yang, X.; Lv, S.; Yang, X. Novel Combination Therapies for the Treatment of Bladder Cancer. Front. Oncol. 2021, 10, 3163. [CrossRef]

7. Gupta, S.C.; Patchva, S.; Aggarwal, B.B. Therapeutic Roles of Curcumin: Lessons Learned from Clinical Trials. AAPS J. 2012, 15, 195-218. [CrossRef]

8. Kunnumakkara, A.B.; Bordoloi, D.; Padmavathi, G.; Monisha, J.; Roy, N.; Prasad, S.; Aggarwal, B.B. Curcumin, the golden nutraceutical: Multitargeting for multiple chronic diseases. Br. J. Pharmacol. 2016, 174, 1325-1348. [CrossRef]

9. Hanahan, D.; Weinberg, R.A. Hallmarks of Cancer: The Next Generation. Cell 2011, 144, 646-674. [CrossRef]

10. Panda, M.; Biswal, B.K. Cell signaling and cancer: A mechanistic insight into drug resistance. Mol. Biol. Rep. 2019, 46, 5645-5659. [CrossRef]

11. Shah, M.A.; Schwartz, G.K. Cell cycle-mediated drug resistance: An emerging concept in cancer therapy. Clin. Cancer Res. 2001, 7 , 2168-2181.

12. Otto, T.; Sicinski, P. Cell cycle proteins as promising targets in cancer therapy. Nat. Rev. Cancer 2017, 17, 93-115. [CrossRef] [PubMed] 
13. Abukhdeir, A.; Park, B.H. p21 and p27: Roles in carcinogenesis and drug resistance. Expert Rev. Mol. Med. 2008, 10, e19. [CrossRef] [PubMed]

14. Hientz, K.; Mohr, A.; Bhakta-Guha, D.; Efferth, T. The role of p53 in cancer drug resistance and targeted chemotherapy. Oncotarget 2017, 8, 8921-8946. [CrossRef]

15. Carneiro, B.A.; El-Deiry, W.S. Targeting apoptosis in cancer therapy. Nat. Rev. Clin. Oncol. 2020, 17, 395-417. [CrossRef] [PubMed]

16. Wong, R.S.Y. Apoptosis in cancer: From pathogenesis to treatment. J. Exp. Clin. Cancer Res. 2011, 30, 87. [CrossRef]

17. Koff, J.L.; Ramachandiran, S.; Bernal-Mizrachi, L. A Time to Kill: Targeting Apoptosis in Cancer. Int. J. Mol. Sci. 2015, 16, 2942-2955. [CrossRef]

18. Raisova, M.; Hossini, A.M.; Eberle, J.; Riebeling, C.; Orfanos, C.E.; Geilen, C.C.; Wieder, T.; Sturm, I.; Daniel, P.T. The Bax/Bcl-2 Ratio Determines the Susceptibility of Human Melanoma Cells to CD95/Fas-Mediated Apoptosis. J. Investig. Dermatol. 2001, 117, 333-340. [CrossRef] [PubMed]

19. Gonzalez, M.S.; De Brasi, C.D.; Bianchini, M.; Gargallo, P.; Moiraghi, B.; Bengió, R.; Larripa, I.B. BAX/BCL-XL gene expres-sion ratio inversely correlates with disease progression in chronic myeloid leukemia. Blood Cells Mol. Dis. 2010, 45, 192-196. [CrossRef]

20. Inao, T.; Iida, Y.; Moritani, T.; Okimoto, T.; Tanino, R.; Kotani, H.; Harada, M. Bcl-2 inhibition sensitizes triple-negative hu-man breast cancer cells to doxorubicin. Oncotarget 2018, 9, 25545-25556. [CrossRef] [PubMed]

21. Zhang, Y.; Zhang, B. TRAIL Resistance of Breast Cancer Cells Is Associated with Constitutive Endocytosis of Death Receptors 4 and 5. Mol. Cancer Res. 2008, 6, 1861-1871. [CrossRef]

22. Wong, S.H.M.; Kong, W.Y.; Fang, C.-M.; Loh, H.-S.; Chuah, L.-H.; Abdullah, S.; Ngai, S.C. The TRAIL to cancer therapy: Hindrances and potential solutions. Crit. Rev. Oncol. 2019, 143, 81-94. [CrossRef]

23. Abdullah, L.N.; Chow, E. Mechanisms of chemoresistance in cancer stem cells. Clin. Transl. Med. 2013, 2, 3. [CrossRef] [PubMed]

24. Robey, R.; Pluchino, K.M.; Hall, M.D.; Fojo, A.T.; Bates, S.E.; Gottesman, M.M. Revisiting the role of ABC transporters in multidrug-resistant cancer. Nat. Rev. Cancer 2018, 18, 452-464. [CrossRef]

25. Abdallah, H.M.; Al-Abd, A.M.; El-Dine, R.S.; El-Halawany, A.M. P-glycoprotein inhibitors of natural origin as potential tumor chemo-sensitizers: A review. J. Adv. Res. 2015, 6, 45-62. [CrossRef] [PubMed]

26. Housman, G.; Byler, S.; Heerboth, S.; Lapinska, K.; Longacre, M.; Snyder, N.; Sarkar, S. Drug resistance in cancer: An over-view. Cancers 2014, 6, 1769-1792. [CrossRef]

27. Robinson, K.; Tiriveedhi, V. Perplexing Role of P-Glycoprotein in Tumor Microenvironment. Front. Oncol. 2020, 10, 265. [CrossRef] [PubMed]

28. Du, B.; Shim, J.S. Targeting Epithelial-Mesenchymal Transition (EMT) to Overcome Drug Resistance in Cancer. Molecules 2016, 21, 965. [CrossRef] [PubMed]

29. Ashrafizadeh, M.; Zarrabi, A.; Hushmandi, K.; Kalantari, M.; Mohammadinejad, R.; Javaheri, T.; Sethi, G. Association of the Epithelial-Mesenchymal Transition (EMT) with Cisplatin Resistance. Int. J. Mol. Sci. 2020, 21, 4002. [CrossRef] [PubMed]

30. Xu, J.; Lamouille, S.; Derynck, R. TGF-beta-induced epithelial to mesenchymal transition. Cell Res. 2009, 19, 156-172. [CrossRef]

31. Witta, S.E.; Gemmill, R.M.; Hirsch, F.R.; Coldren, C.D.; Hedman, K.; Ravdel, L.; Helfrich, B.; Dziadziuszko, R.; Chan, D.C.; Sugita, M.; et al. Restoring E-Cadherin Expression Increases Sensitivity to Epidermal Growth Factor Receptor Inhibitors in Lung Cancer Cell Lines. Cancer Res. 2006, 66, 944-950. [CrossRef]

32. Singh, A.; Settleman, J. EMT, cancer stem cells and drug resistance: An emerging axis of evil in the war on cancer. Oncogene 2010, 29, 4741-4751. [CrossRef] [PubMed]

33. Loges, S.; Schmidt, T.; Carmeliet, P. Mechanisms of Resistance to Anti-Angiogenic Therapy and Development of Third-Generation Anti-Angiogenic Drug Candidates. Genes Cancer 2010, 1, 12-25. [CrossRef]

34. Zimna, A.; Kurpisz, M. Hypoxia-Inducible Factor-1 in Physiological and Pathophysiological Angiogenesis: Applications and Therapies. BioMed Res. Int. 2015, 2015, 1-13. [CrossRef]

35. Xia, Y.; Jiang, L.; Zhong, T. The role of HIF-1 $\alpha$ in chemo-/radioresistant tumors. OncoTargets Ther. 2018, 11, 3003-3011. [CrossRef]

36. Phi, L.T.H.; Sari, I.N.; Yang, Y.-G.; Lee, S.-H.; Jun, N.; Kim, K.S.; Lee, Y.K.; Kwon, H.Y. Cancer Stem Cells (CSCs) in Drug Resistance and their Therapeutic Implications in Cancer Treatment. Stem Cells Int. 2018, 2018, 1-16. [CrossRef]

37. Zhao, J. Cancer stem cells and chemoresistance: The smartest survives the raid. Pharmacol. Ther. 2016, 160, 145-158. [CrossRef]

38. Cho, Y.; Kim, Y.K. Cancer Stem Cells as a Potential Target to Overcome Multidrug Resistance. Front. Oncol. 2020, 10, 764. [CrossRef] [PubMed]

39. Prieto-Vila, M.; Takahashi, R.-U.; Usuba, W.; Kohama, I.; Ochiya, T. Drug Resistance Driven by Cancer Stem Cells and Their Niche. Int. J. Mol. Sci. 2017, 18, 2574. [CrossRef]

40. Prasad, S.; Gupta, S.C.; Tyagi, A.K.; Aggarwal, B.B. Curcumin, a component of golden spice: From bedside to bench and back. Biotechnol. Adv. 2014, 32, 1053-1064. [CrossRef]

41. Wong, K.E.; Ngai, S.C.; Chan, K.-G.; Lee, L.-H.; Goh, B.-H.; Chuah, L.-H. Curcumin Nanoformulations for Colorectal Cancer: A Review. Front. Pharmacol. 2019, 10, 152. [CrossRef]

42. Anand, P.; Sundaram, C.; Jhurani, S.; Kunnumakkara, A.B.; Aggarwal, B.B. Curcumin and cancer: An "old-age" disease with an "age-old" solution. Cancer Lett. 2008, 267, 133-164. [CrossRef] [PubMed]

43. Praditya, D.; Kirchhoff, L.; Brüning, J.; Rachmawati, H.; Steinmann, J.; Steinmann, E. Anti-infective Properties of the Golden Spice Curcumin. Front. Microbiol. 2019, 10, 912. [CrossRef] [PubMed] 
44. Fabianowska-Majewska, K.; Kaufman-Szymczyk, A.; Szymanska-Kolba, A.; Jakubik, J.; Majewski, G.; Lubecka, K. Curcumin from Turmeric Rhizome: A Potential Modulator of DNA Methylation Machinery in Breast Cancer Inhibition. Nutrients 2021, 13, 332. [CrossRef] [PubMed]

45. Song, X.; Zhang, M.; Dai, E.; Luo, Y. Molecular targets of curcumin in breast cancer (Review). Mol. Med. Rep. 2019, 19, 23-29. [CrossRef] [PubMed]

46. Pricci, M.; Girardi, B.; Giorgio, F.; Losurdo, G.; Ierardi, E.; Di Leo, A. Curcumin and Colorectal Cancer: From Basic to Clinical Evidences. Int. J. Mol. Sci. 2020, 21, 2364. [CrossRef]

47. Ashrafizadeh, M.; Najafi, M.; Makvandi, P.; Zarrabi, A.; Farkhondeh, T.; Samarghandian, S. Versatile role of curcumin and its derivatives in lung cancer therapy. J. Cell. Physiol. 2020, 235, 9241-9268. [CrossRef] [PubMed]

48. Bimonte, S.; Barbieri, A.; Leongito, M.; Piccirillo, M.; Giudice, A.; Pivonello, C.; de Angelis, C.; Granata, V.; Palaia, R.; Izzo, F. Curcumin AntiCancer Studies in Pancreatic Cancer. Nutrients 2016, 8, 433. [CrossRef]

49. Teiten, M.-H.; Gaascht, F.; Eifes, S.; Dicato, M.; Diederich, M. Chemopreventive potential of curcumin in prostate cancer. Genes Nutr. 2010, 5, 61-74. [CrossRef] [PubMed]

50. Goel, A.; Boland, C.; Chauhan, D.P. Specific inhibition of cyclooxygenase-2 (COX-2) expression by dietary curcumin in HT-29 human colon cancer cells. Cancer Lett. 2001, 172, 111-118. [CrossRef]

51. Marquardt, J.U.; Gomez-Quiroz, L.; Arreguin Camacho, L.O.; Pinna, F.; Lee, Y.-H.; Kitade, M.; Domínguez, M.P.; Castven, D.; Breuhahn, K.; Conner, E.A.; et al. Curcumin effectively inhibits oncogenic NF- $\mathrm{kB}$ signaling and restrains stemness features in liver cancer. J. Hepatol. 2015, 63, 661-669. [CrossRef] [PubMed]

52. Ghasemi, F.; Shafiee, M.; Banikazemi, Z.; Pourhanifeh, M.H.; Khanbabaei, H.; Shamshirian, A.; Amiri Moghadam, S.; ArefNezhad, R.; Sahebkar, A.; Avan, A.; et al. Curcumin inhibits NF-kB and Wnt/ $\beta$-catenin pathways in cervical cancer cells. Pathol. Res. Pract. 2019, 215, 152556. [CrossRef]

53. Shaikh, S.; Shaikh, J.; Naba, Y.S.; Doke, K.; Ahmed, K.; Yusufi, M. Curcumin: Reclaiming the lost ground against cancer resistance. Cancer Drug Resist. 2021, 4, 298-320.

54. Johnson, S.M.; Gulhati, P.A.T.; Arrieta, I.; Wang, X.; Uchida, T.; Gao, T.; Evers, B.M. Curcumin Inhibits Proliferation of Colo-rectal Carcinoma by Modulating Akt/mTOR Signaling. Anticancer Res. 2009, 29, 3185-3190.

55. Seo, B.R.; Min, K.-J.; Cho, I.J.; Kim, S.C.; Kwon, T.K. Correction: Curcumin Significantly Enhances Dual PI3K/Akt and mTOR Inhibitor NVP-BEZ235-Induced Apoptosis in Human Renal Carcinoma Caki Cells through Down-Regulation of p53-Dependent Bcl-2 Expression and Inhibition of Mcl-1 Protein Stability. PLoS ONE 2016, 11, e0151886. [CrossRef]

56. Wang, H.; Zhang, K.; Liu, J.; Yang, J.; Tian, Y.; Yang, C.; Li, Y.; Shao, M.; Su, W.; Song, N. Curcumin Regulates Cancer Progression: Focus on ncRNAs and Molecular Signaling Pathways. Front. Oncol. 2021, 11, 1202.

57. Wang, S.; Yu, S.; Shi, W.; Ge, L.; Yu, X.; Fan, J.; Zhang, J. Curcumin Inhibits the Migration and Invasion of Mouse Hepatoma Hca-F Cells Through Down-regulating Caveolin-1 Expression and Epidermal Growth Factor Receptor Signaling. IUBMB Life 2011, 63, 775-782. [CrossRef]

58. Kunnumakkara, A.B.; Bordoloi, D.; Harsha, C.; Banik, K.; Gupta, S.C.; Aggarwal, B.B. Curcumin mediates anticancer effects by modulating multiple cell signaling pathways. Clin. Sci. 2017, 131, 1781-1799. [CrossRef]

59. Hong, J.H.; Ahn, K.S.; Bae, E.; Jeon, S.S.; Choi, H.Y. The effects of curcumin on the invasiveness of prostate cancer in vitro and in vivo. Prostate Cancer Prostatic Dis. 2006, 9, 147-152. [CrossRef]

60. Bachmeier, B.E.; Killian, P.H.; Melchart, D. The Role of Curcumin in Prevention and Management of Metastatic Disease. Int. J. Mol. Sci. 2018, 19, 1716. [CrossRef]

61. Kuttikrishnan, S.; Siveen, K.S.; Prabhu, K.S.; Khan, A.Q.; Ahmed, E.I.; Akhtar, S.; Ali, T.A.; Merhi, M.; Dermime, S.; Steinhoff, M.; et al. Curcumin Induces Apoptotic Cell Death via Inhibition of PI3-Kinase/AKT Pathway in B-Precursor Acute Lymphoblastic Leukemia. Front. Oncol. 2019, 9, 484. [CrossRef]

62. Shankar, S.; Srivastava, R.K. Bax and Bak genes are essential for maximum apoptotic response by curcumin, a polyphenolic compound and cancer chemopreventive agent derived from turmeric, Curcuma longa. Carcinogenesis 2007, 28, 1277-1286. [CrossRef] [PubMed]

63. Chakraborty, G.; Jain, S.; Kale, S.; Raja, R.; Kumar, S.; Mishra, R.; Kundu, G.C. Curcumin suppresses breast tumor angiogenesis by abrogating osteopontin-induced VEGF expression. Mol. Med. Rep. 2008, 1, 641-646. [CrossRef] [PubMed]

64. Palmer, A.; Sorger, P.K. Combination Cancer Therapy Can Confer Benefit via Patient-to-Patient Variability without Drug Additivity or Synergy. Cell 2017, 171, 1678-1691.e13. [CrossRef] [PubMed]

65. Jiang, M.; Huang, O.; Zhang, X.; Xie, Z.; Shen, A.; Liu, H.; Geng, M.; Shen, K. Curcumin induces cell death and restores tamoxifen sensitivity in the antiestrogen-resistant breast cancer cell lines MCF-7/LCC2 and MCF-7/LCC9. Molecules 2013, 18, 701-720. [CrossRef] [PubMed]

66. Geng, C.; Li, J.; Ding, F.; Wu, G.; Yang, Q.; Sun, Y.; Zhang, Z.; Dong, T.; Tian, X. Curcumin suppresses 4-hydroxytamoxifen resistance in breast cancer cells by targeting SLUG/Hexokinase 2 pathway. Biochem. Biophys. Res. Commun. 2016, 473, 147-153. [CrossRef]

67. Lai, H.-W.; Chien, S.-Y.; Kuo, S.-J.; Tseng, L.-M.; Lin, H.-Y.; Chi, C.-W.; Chen, D.-R. The Potential Utility of Curcumin in the Treatment of HER-2-Overexpressed Breast Cancer: An in vitro and in vivo Comparison Study with Herceptin. Evid. Based Complement. Altern. Med. 2012, 2012, 486568. [CrossRef] 
68. Zhan, Y.; Chen, Y.; Liu, R.; Zhang, H.; Zhang, Y. Potentiation of paclitaxel activity by curcumin in human breast cancer cell by modulating apoptosis and inhibiting EGFR signaling. Arch. Pharmacal Res. 2014, 37, 1086-1095. [CrossRef]

69. Aggarwal, B.B.; Shishodia, S.; Takada, Y.; Banerjee, S.; Newman, R.A.; Bueso-Ramos, C.E.; Price, J.E. Curcumin Suppresses the Paclitaxel-Induced Nuclear Factor- $\mathrm{B}$ Pathway in Breast Cancer Cells and Inhibits Lung Metastasis of Human Breast Cancer in Nude Mice. Clin. Cancer Res. 2005, 11, 7490-7498. [CrossRef]

70. Quispe-Soto, E.T.; Calaf, G.M. Effect of curcumin and paclitaxel on breast carcinogenesis. Int. J. Oncol. 2016, 49, 2569-2577. [CrossRef]

71. Calaf, G.M.; Ponce-Cusi, R.; Carrión, F. Curcumin and paclitaxel induce cell death in breast cancer cell lines. Oncol. Rep. 2018, 40, 2381-2388. [CrossRef] [PubMed]

72. Wen, C.; Fu, L.; Huang, J.; Dai, Y.; Wang, B.; Xu, G.; Wu, L.; Zhou, H. Curcumin reverses doxorubicin resistance via inhibition the efflux function of ABCB4 in doxorubicin-resistant breast cancer cells. Mol. Med. Rep. 2019, 19, 5162-5168. [CrossRef]

73. Abd-Ellatef, G.-E.F.; Gazzano, E.; Chirio, D.; Hamed, A.R.; Belisario, D.C.; Zuddas, C.; Peira, E.; Rolando, B.; Kopecka, J.; Marie, M.A.S.; et al. Curcumin-Loaded Solid Lipid Nanoparticles Bypass P-Glycoprotein Mediated Doxorubicin Resistance in Triple Negative Breast Cancer Cells. Pharmaceutics 2020, 12, 96. [CrossRef] [PubMed]

74. Saxena, A.R.; Ilic, Z.; Sripada, V.; Crawford, D.R. Lower concentrations of curcumin inhibit Her2-Akt pathway components in human breast cancer cells, and other dietary botanicals potentiate this and lapatinib inhibition. Nutr. Res. 2020, 78, 93-104. [CrossRef]

75. Somers-Edgar, T.J.; Scandlyn, M.J.; Stuart, E.C.; Le Nedelec, M.J.; Valentine, S.P.; Rosengren, R.J. The combination of epigallocatechin gallate and curcumin suppresses ER $\alpha$-breast cancer cell growth in vitro and in vivo. Int. J. Cancer 2008, 122, $1966-1971$. [CrossRef]

76. Wang, K.; Zhang, C.; Bao, J.; Jia, X.; Liang, Y.; Wang, X.; Chen, M.; Su, H.; Li, P.; Wan, J.-B.; et al. Synergistic chemopreventive effects of curcumin and berberine on human breast cancer cells through induction of apoptosis and autophagic cell death. Sci. Rep. 2016, 6, 26064. [CrossRef] [PubMed]

77. Shakibaei, M.; Kraehe, P.; Popper, B.; Shayan, P.; Goel, A.; Buhrmann, C. Curcumin potentiates antitumor activity of 5-fluorouracil in a 3D alginate tumor microenvironment of colorectal cancer. BMC Cancer 2015, 15, 1-15. [CrossRef]

78. He, W.-t.; Zhu, Y.-h.; Zhang, T.; Abulimiti, P.; Zeng, F.-y.; Zhang, L.-p.; Luo, L.-j.; Xie, X.-m.; Zhang, H.-1. Curcumin Reverses 5-Fluorouracil Resistance by Promoting Human Colon Cancer HCT-8/5-FU Cell Apoptosis and Down-regulating Heat Shock Protein 27 and P-Glycoprotein. Chin. J. Integr. Med. 2019, 25, 416-424. [CrossRef]

79. Lu, Y.; Zhang, R.; Zhang, X.; Zhang, B.; Yao, Q. Curcumin may reverse 5-fluorouracil resistance on colonic cancer cells by regulating TET1-NKD-Wnt signal pathway to inhibit the EMT progress. Biomed. Pharmacother. 2020, 129, 110381. [CrossRef]

80. Shakibaei, M.; Mobasheri, A.; Lueders, C.; Busch, F.; Shayan, P.; Goel, A. Curcumin enhances the effect of chemotherapy against colorectal cancer cells by inhibition of NF-kB and Src protein kinase signaling pathways. PLoS ONE 2013, 8, e57218. [CrossRef]

81. Zhang, P.; Lai, Z.; Chen, H.-F.; Zhang, M.; Wang, A.; Jia, T.; Sun, W.-Q.; Zhu, X.-M.; Chen, X.-F.; Zhao, Z.; et al. Curcumin synergizes with 5-fluorouracil by impairing AMPK/ULK1-dependent autophagy, AKT activity and enhancing apoptosis in colon cancer cells with tumor growth inhibition in xenograft mice. J. Exp. Clin. Cancer Res. 2017, 36, 1-12. [CrossRef]

82. Yin, J.; Wang, L.; Wang, Y.; Shen, H.; Wang, X.; Wu, L. Curcumin reverses oxaliplatin resistance in human colorectal cancer via regulation of TGF- $\beta /$ Smad2/3 signaling pathway. OncoTargets Targets Ther. 2019, 12, 3893-3903. [CrossRef] [PubMed]

83. Huang, Y.-F.; Zhu, D.-J.; Chen, X.-W.; Chen, Q.-K.; Luo, Z.-T.; Liu, C.-C.; Wang, G.-X.; Zhang, W.-J.; Liao, N.-Z. Curcumin enhances the effects of irinotecan on colorectal cancer cells through the generation of reactive oxygen species and activation of the endoplasmic reticulum stress pathway. Oncotarget 2017, 8, 40264-40275. [CrossRef] [PubMed]

84. Su, P.; Yang, Y.; Wang, G.; Chen, X.; Ju, Y. Curcumin attenuates resistance to irinotecan via induction of apoptosis of cancer stem cells in chemoresistant colon cancer cells. Int. J. Oncol. 2018, 53, 1343-1353. [CrossRef]

85. Nautiyal, J.; Kanwar, S.S.; Yu, Y.; Majumdar, A.P.N. Combination of dasatinib and curcumin eliminates chemo-resistant colon cancer cells. J. Mol. Signal. 2011, 6, 7. [CrossRef] [PubMed]

86. Patel, B.B.; Sengupta, R.; Qazi, S.; Vachhani, H.; Yu, Y.; Rishi, A.K.; Majumdar, A.P. Curcumin enhances the effects of 5-fluorouracil and oxaliplatin in mediating growth inhibition of colon cancer cells by modulating EGFR and IGF-1R. Int. J. Cancer 2008, 122, 267-273. [CrossRef]

87. Patel, B.B.; Gupta, D.; Elliott, A.A.; Sengupta, V.; Yu, Y.; Majumdar, A.P.N. Curcumin targets FOLFOX-surviving colon cancer cells via inhibition of EGFRs and IGF-1R. Anticancer Res. 2010, 30, 319-325.

88. James, M.I.; Iwuji, C.; Irving, G.; Karmokar, A.; Higgins, J.A.; Griffin-Teal, N.; Thomas, A.; Greaves, P.; Cai, H.; Patel, S.R.; et al. Curcumin inhibits cancer stem cell phenotypes in ex vivo models of colorectal liver metastases, and is clinically safe and tolerable in combination with FOLFOX chemotherapy. Cancer Lett. 2015, 364, 135-141. [CrossRef]

89. Yu, Y.; Kanwar, S.; Patel, B.B.; Nautiyal, J.; Sarkar, F.H.; Majumdar, A.P. Elimination of Colon Cancer Stem-Like Cells by the Combination of Curcumin and FOLFOX. Transl. Oncol. 2009, 2, 321-328. [CrossRef]

90. Yue, G.G.-L.; Kwok, H.-F.; Lee, J.K.-M.; Jiang, L.; Wong, E.C.-W.; Gao, S.; Wong, H.-L.; Li, L.; Chan, K.-M.; Leung, P.-C.; et al. Combined therapy using bevacizumab and turmeric ethanolic extract (with absorbable curcumin) exhibited beneficial efficacy in colon cancer mice. Pharmacol. Res. 2016, 111, 43-57. [CrossRef]

91. Montgomery, A.; Adeyeni, T.; San, K.; Heuertz, R.M.; Ezekiel, U.R. Curcumin Sensitizes Silymarin to Exert Synergistic Anti-cancer Activity in Colon Cancer Cells. J. Cancer 2016, 7, 1250-1257. [CrossRef] [PubMed] 
92. Majumdar, A.P.N.; Banerjee, S.; Nautiyal, J.; Patel, B.B.; Patel, V.; Du, J.; Yu, Y.; Elliott, A.A.; Levi, E.; Sarkar, F.H. Curcumin Synergizes With Resveratrol to Inhibit Colon Cancer. Nutr. Cancer 2009, 61, 544-553. [CrossRef] [PubMed]

93. Xin, J.; Jue, W.; Huifen, S.; Ran, R.; Kai, X.; Xiangming, T.; Weiping, Z.; Li, F. Curcumin co-treatment ameliorates resistance to gefitinib in drug-resistant NCI-H1975 lung cancer cells. J. Tradit. Chin. Med. 2017, 37, 355-360. [CrossRef]

94. Lee, J.-Y.; Lee, Y.-M.; Chang, G.-C.; Yu, S.-L.; Hsieh, W.-Y.; Chen, J.J.; Chen, H.-W.; Yang, P.-C. Curcumin Induces EGFR Degradation in Lung Adenocarcinoma and Modulates p38 Activation in Intestine: The Versatile Adjuvant for Gefitinib Therapy. PLoS ONE 2011, 6, e23756. [CrossRef]

95. Chen, P.; Huang, H.-P.; Wang, Y.; Jin, J.; Long, W.-G.; Chen, K.; Zhao, X.-H.; Chen, C.-G.; Li, J. Curcumin overcome primary gefitinib resistance in non-small-cell lung cancer cells through inducing autophagy-related cell death. J. Exp. Clin. Cancer Res. 2019, 38, 1-17. [CrossRef] [PubMed]

96. Li, S.; Liu, Z.; Zhu, F.; Fan, X.; Wu, X.; Zhao, H.; Jiang, L. Curcumin Lowers Erlotinib Resistance in Non-Small Cell Lung Carcinoma Cells With Mutated EGF Receptor. Oncol. Res. Featur. Preclin. Clin. Cancer Ther. 2014, 21, 137-144. [CrossRef]

97. Yamauchi, Y.; Izumi, Y.; Yamamoto, J.; Nomori, H. Coadministration of Erlotinib and Curcumin Augmentatively Reduces Cell Viability in Lung Cancer Cells. Phytother. Res. 2014, 28, 728-735. [CrossRef]

98. Ye, M.-X.; Zhao, Y.-L.; Li, Y.; Miao, Q.; Li, Z.-K.; Ren, X.-L.; Song, L.-Q.; Yin, H.; Zhang, J. Curcumin reverses cis-platin resistance and promotes human lung adenocarcinoma A549/DDP cell apoptosis through HIF-1 $\alpha$ and caspase-3 mechanisms. Phytomedicine 2012, 19, 779-787. [CrossRef]

99. Chen, P.; Li, J.; Jiang, H.-G.; Lan, T.; Chen, Y.-C. Curcumin reverses cisplatin resistance in cisplatin-resistant lung caner cells by inhibiting FA/BRCA pathway. Tumor Biol. 2015, 36, 3591-3599. [CrossRef]

100. Lin, C.-Y.; Hung, C.-C.; Wang, C.C.; Lin, H.-Y.; Huang, S.-H.; Sheu, M.-J. Demethoxycurcumin sensitizes the response of non-small cell lung cancer to cisplatin through downregulation of TP and ERCC1-related pathways. Phytomedicine 2019, 53, 28-36. [CrossRef]

101. Wang, H.-J.; Yang, Z.-X.; Dai, X.-T.; Chen, Y.-F.; Yang, H.-P.; Zhou, X.-D. Bisdemethoxycurcumin sensitizes cisplatin-resistant lung cancer cells to chemotherapy by inhibition of CA916798 and PI3K/AKT signaling. Apoptosis 2017, 22, 1157-1168. [CrossRef] [PubMed]

102. Baharuddin, P.; Satar, N.; Fakiruddin, K.S.; Zakaria, N.; Lim, M.N.; Yusoff, N.M.; Zakaria, Z.; Yahaya, B.H. Curcumin im-proves the efficacy of cisplatin by targeting cancer stem-like cells through p21 and cyclin D1-mediated tumour cell inhibition in non-small cell lung cancer cell lines. Oncol. Rep. 2016, 35, 13-25. [CrossRef] [PubMed]

103. Cai, Y.; Sheng, Z.; Liang, S. Radiosensitization effects of curcumin plus cisplatin on non-small cell lung cancer A549 cells. Oncol. Lett. 2019, 18, 529-534. [CrossRef] [PubMed]

104. Kang, J.H.; Kang, H.S.; Kim, I.K.; Lee, H.Y.; Ha, J.H.; Yeo, C.D.; Kang, H.H.; Moon, H.S.; Lee, S.H. Curcumin sensitizes human lung cancer cells to apoptosis and metastasis synergistically combined with carboplatin. Exp. Biol. Med. 2015, 240, 1416-1425. [CrossRef]

105. Lu, Y.; Wang, J.; Liu, L.; Yu, L.; Zhao, N.; Zhou, X.; Lu, X. Curcumin increases the sensitivity of Paclitaxel-resistant NSCLC cells to Paclitaxel through microRNA-30c-mediated MTA1 reduction. Tumor Biol. 2017, 39, 1010428317698353. [CrossRef]

106. Boztas, A.O.; Karakuzu, O.; Galante, G.; Ugur, Z.; Kocabas, F.; Altuntas, C.Z.; Yazaydin, A.O. Synergistic Interaction of Paclitaxel and Curcumin with Cyclodextrin Polymer Complexation in Human Cancer Cells. Mol. Pharm. 2013, 10, 2676-2683. [CrossRef]

107. Zhang, D.; Xu, Q.; Wang, N.; Yang, Y.; Liu, J.; Yu, G.; Yang, X.; Xu, H.; Wang, H. A complex micellar system co-delivering curcumin with doxorubicin against cardiotoxicity and tumor growth. Int. J. Nanomed. 2018, 13, 4549-4561. [CrossRef]

108. Gu, Y.; Li, J.; Li, Y.; Song, L.; Li, D.; Peng, L.; Wan, Y.; Hua, S. Nanomicelles loaded with doxorubicin and curcumin for alleviating multidrug resistance in lung cancer. Int. J. Nanomed. 2016, 11, 5757-5770. [CrossRef]

109. Hong, Y.; Che, S.; Hui, B.; Yang, Y.; Wang, X.; Zhang, X.; Qiang, Y.; Ma, H. Lung cancer therapy using doxorubicin and curcumin combination: Targeted prodrug based, pH sensitive nanomedicine. Biomed. Pharmacother. 2019, 112, 108614. [CrossRef]

110. Liu, P.; Ying, Q.; Liu, H.; Yu, S.; Bu, L.; Shao, L.; Li, X. Curcumin enhances anti-cancer efficacy of either gemcitabine or docetaxel on pancreatic cancer cells. Oncol. Rep. 2020, 44, 1393-1402. [CrossRef]

111. Kunnumakkara, A.B.; Guha, S.; Krishnan, S.; Diagaradjane, P.; Gelovani, J.; Aggarwal, B.B. Curcumin Potentiates Antitumor Activity of Gemcitabine in an Orthotopic Model of Pancreatic Cancer through Suppression of Proliferation, Angiogenesis, and Inhibition of Nuclear Factor-kB-Regulated Gene Products. Cancer Res. 2007, 67, 3853-3861. [CrossRef]

112. Yoshida, K.; Toden, S.; Ravindranathan, P.; Han, H.; Goel, A. Curcumin sensitizes pancreatic cancer cells to gemcitabine by attenuating PRC2 subunit EZH2, and the lncRNA PVT1 expression. Carcinogenesis 2017, 38, 1036-1046. [CrossRef]

113. Lev-Ari, S.; Zinger, H.; Kazanov, D.; Yona, D.; Ben-Yosef, R.; Starr, A.; Figer, A.; Arber, N. Curcumin synergistically potentiates the growth inhibitory and pro-apoptotic effects of celecoxib in pancreatic adenocarcinoma cells. Biomed. Pharmacother. 2005, 59, S276-S280. [CrossRef]

114. Li, Y.; Revalde, J.L.; Reid, G.; Paxton, J.W. Modulatory effects of curcumin on multi-drug resistance-associated protein 5 in pancreatic cancer cells. Cancer Chemother. Pharmacol. 2011, 68, 603-610. [CrossRef]

115. Sankpal, U.; Abdelrahim, M.; Connelly, S.F.; Lee, C.M.; Madero-Visbal, R.; Colon, J.; Smith, J.; Safe, S.; Maliakal, P.; Basha, R. Small molecule tolfenamic acid inhibits PC-3 cell proliferation and invasion in vitro, and tumor growth in orthotopic mouse model for prostate cancer. Prostate 2012, 72, 1648-1658. [CrossRef] [PubMed]

116. Thakkar, A.; Sutaria, D.; Grandhi, B.K.; Wang, J.; Prabhu, S. The molecular mechanism of action of aspirin, curcumin and sulforaphane combinations in the chemoprevention of pancreatic cancer. Oncol. Rep. 2013, 29, 1671-1677. [CrossRef] [PubMed] 
117. Thakkar, A.; Chenreddy, S.; Thio, A.; Khamas, W.; Wang, J.; Prabhu, S. Preclinical systemic toxicity evaluation of chi-tosan-solid lipid nanoparticle-encapsulated aspirin and curcumin in combination with free sulforaphane in BALB/c mice. Int. J. Nanomed. 2016, 11, 3265-3276.

118. Thakkar, A.; Desai, P.; Chenreddy, S.; Modi, J.; Thio, A.; Khamas, W.; Ann, D.; Wang, J.; Prabhu, S. Novel nano-drug com-bination therapeutic regimen demonstrates significant efficacy in the transgenic mouse model of pancreatic ductal adenocarcinoma. Am. $J$. Cancer Res. 2018, 8, 2005-2019.

119. Parasramka, M.A.; Gupta, S.V. Synergistic Effect of Garcinol and Curcumin on Antiproliferative and Apoptotic Activity in Pancreatic Cancer Cells. J. Oncol. 2012, 2012, 1-8. [CrossRef] [PubMed]

120. Halder, R.C.; Almasi, A.; Sagong, B.; Leung, J.; Jewett, A.; Fiala, M. Curcuminoids and $\omega-3$ fatty acids with anti-oxidants potentiate cytotoxicity of natural killer cells against pancreatic ductal adenocarcinoma cells and inhibit interferon $\gamma$ production. Front. Physiol. 2015, 6, 129. [CrossRef]

121. Banerjee, S.; Singh, S.K.; Chowdhury, I.; Lillard, J.W., Jr.; Singh, R. Combinatorial effect of curcumin with docetaxel modulates apoptotic and cell survival molecules in prostate cancer. Front. Biosci. 2017, 9, 235-245.

122. Yan, J.; Wang, Y.; Jia, Y.; Liu, S.; Tian, C.; Pan, W.; Liu, X.; Wang, H. Co-delivery of docetaxel and curcumin prodrug via dual-targeted nanoparticles with synergistic antitumor activity against prostate cancer. Biomed. Pharmacother. 2017, 88, 374-383. [CrossRef]

123. Eslami, S.S.; Jafari, D.; Montazeri, H.; Sadeghizadeh, M.; Tarighi, P. Combination of Curcumin and Metformin Inhibits Cell Growth and Induces Apoptosis without Affecting the Cell Cycle in LNCaP Prostate Cancer Cell Line. Nutr. Cancer 2020, 1-14. [CrossRef]

124. Shankar, S.; Chen, Q.; Sarva, K.; Siddiqui, I.; Srivastava, R.K. Curcumin enhances the apoptosis-inducing potential of TRAIL in prostate cancer cells: Molecular mechanisms of apoptosis, migration and angiogenesis. J. Mol. Signal. 2007, 2, 10. [CrossRef]

125. Deeb, D.; Jiang, H.; Gao, X.; Hafner, M.S.; Wong, H.; Divine, G.; Chapman, R.A.; Dulchavsky, S.A.; Gautam, S.C. Curcumin sensitizes prostate cancer cells to tumor necrosis factor-related apoptosis-inducing ligand/Apo2L by inhibiting nuclear factor- $\mathrm{kB}$ through suppression of IKB $\alpha$ phosphorylation. Mol. Cancer Ther. 2004, 3, 803-812. [PubMed]

126. Andrzejewski, T.; Deeb, D.; Gao, X.; Danyluk, A.; Arbab, A.; Dulchavsky, S.; Gautam, S. Therapeutic Efficacy of Curcu-min/TRAIL Combination Regimen for Hormone-Refractory Prostate Cancer. Oncol. Res. 2008, 17, 257-267. [CrossRef]

127. Eom, D.-W.; Lee, J.H.; Kim, Y.-J.; Hwang, G.S.; Kim, S.-N.; Kwak, J.H.; Cheon, G.J.; Kim, K.H.; Jang, H.-J.; Ham, J.; et al. Synergistic effect of curcumin on epigallocatechin gallate-induced anticancer action in PC3 prostate cancer cells. BMB Rep. 2015, 48, 461-466. [CrossRef]

128. Wang, P.; Wang, B.; Chung, S.; Wu, Y.; Henning, S.M.; Vadgama, J.V. Increased chemopreventive effect by combining arctigenin, green tea polyphenol and curcumin in prostate and breast cancer cells. RSC Adv. 2014, 4, 35242-35250. [CrossRef]

129. Guo, W.; Wu, X.; Li, Y.; Gao, J.; Wang, F.; Jin, Y.; Chong, T.; Malhotra, A. Evaluation of biophysical as well as biochemical potential of curcumin and resveratrol during prostate cancer. J. Drug Target. 2020, 28, 41-45. [CrossRef]

130. Lodi, A.; Saha, A.; Lu, X.; Wang, B.; Sentandreu, E.; Collins, M.; Kolonin, M.G.; DiGiovanni, J.; Tiziani, S. Combinatorial treatment with natural compounds in prostate cancer inhibits prostate tumor growth and leads to key modulations of cancer cell metabolism. NPJ Precis. Oncol. 2017, 1, 1-12. [CrossRef]

131. Sharma, V.; Kumar, L.; Mohanty, S.K.; Maikhuri, J.P.; Rajender, S.; Gupta, G. Sensitization of androgen refractory prostate cancer cells to anti-androgens through re-expression of epigenetically repressed androgen receptor-Synergistic action of quercetin and curcumin. Mol. Cell. Endocrinol. 2016, 431, 12-23. [CrossRef]

132. Xu, T.; Guo, P.; Pi, C.; He, Y.; Yang, H.; Hou, Y.; Feng, X.; Jiang, Q.; Wei, Y.; Zhao, L. Synergistic Effects of Curcumin and 5-Fluorouracil on the Hepatocellular Carcinoma In vivo and vitro through regulating the expression of COX-2 and NF- $\mathrm{B}$. $J$. Cancer 2020, 11, 3955-3964. [CrossRef]

133. Abdallah, F.M.; Helmy, M.W.; Katary, M.A.; Ghoneim, A.I. Synergistic antiproliferative effects of curcumin and celecoxib in hepatocellular carcinoma HepG2 cells. Naunyn-Schmiedeberg's Arch. Pharmacol. 2018, 391, 1399-1410. [CrossRef]

134. Zhang, H.-H.; Zhang, Y.; Cheng, Y.-N.; Gong, F.-L.; Cao, Z.-Q.; Yu, L.-G.; Guo, X.-L. Metformin incombination with curcumin inhibits the growth, metastasis, and angiogenesis of hepatocellular carcinoma in vitro and in vivo. Mol. Carcinog. 2018, 57, 44-56. [CrossRef]

135. Firouzi Amoodizaj, F.; Baghaeifar, S.; Taheri, E.; Farhoudi Sefidan Jadid, M.; Safi, M.; Seyyed Sani, N.; Hajazimian, S.; Isazadeh, A.; Shanehbandi, D. Enhanced anticancer potency of doxorubicin in combination with curcumin in gastric adeno-carcinoma. $J$. Biochemi. Mol. Toxicol. 2020, 34, e22486.

136. Yu, L.-L.; Wu, J.-G.; Dai, N.; Yu, H.-G.; Si, J.-M. Curcumin reverses chemoresistance of human gastric cancer cells by downregulating the NF-kB transcription factor. Oncol. Rep. 2011, 26, 1197-1203.

137. Yang, H.; Huang, S.; Wei, Y.; Cao, S.; Pi, C.; Feng, T.; Liang, J.; Zhao, L.; Ren, G. Curcumin Enhances the Anticancer Effect Of 5-fluorouracil against Gastric Cancer through Down-Regulation of COX-2 and NF- kB Signaling Pathways. J. Cancer 2017, 8 , 3697-3706. [CrossRef]

138. Kamat, A.M.; Tharakan, S.T.; Sung, B.; Aggarwal, B.B. Curcumin Potentiates the Antitumor Effects of Bacillus Calmette-Guerin against Bladder Cancer through the Downregulation of NF-kB and Upregulation of TRAIL Receptors. Cancer Res. 2009, 69, 8958. [CrossRef] 
139. Park, B.H.; Lim, J.E.; Jeon, H.G.; Seo, S.I.; Lee, H.M.; Choi, H.Y.; Jeon, S.S.; Jeong, B.C. Curcumin potentiates antitumor activity of cisplatin in bladder cancer cell lines via ROS-mediated activation of ERK1/2. Oncotarget 2016, 7, 63870-63886. [CrossRef]

140. Guo, Y.; Li, Y.; Shan, Q.; He, G.; Lin, J.; Gong, Y. Curcumin potentiates the anti-leukemia effects of imatinib by downregula-tion of the $\mathrm{AKT} / \mathrm{mTOR}$ pathway and BCR/ABL gene expression in Ph+ acute lymphoblastic leukemia. Int. J. Biochem. Cell Biol. 2015, 65, 1-11. [CrossRef]

141. Santana-Bejarano, U.F.; Bobadilla-Morales, L.; Mendoza-Maldonado, L.; Torres-Anguiano, E.; Barba-Barba, C.C.; Corona-Rivera, J.R.; Corona-Rivera, A. In vitro effect of curcumin in combination with chemotherapy drugs in Ph+ acute lymphoblastic leukemia cells. Oncol. Lett. 2019, 17, 5224-5240. [CrossRef]

142. Mohammadi Kian, M.; Salemi, M.; Bahadoran, M.; Haghi, A.; Dashti, N.; Mohammadi, S.; Rostami, S.; Chahardouli, B.; Ba-bakhani, D.; Nikbakht, M. Curcumin Combined with Thalidomide Reduces Expression of STAT3 and Bcl-xL, Leading to Apoptosis in Acute Myeloid Leukemia Cell Lines. Drug Des. Devel. Ther. 2021, 14, 185-194. [CrossRef]

143. Mutlu Altundağ, E.; Yılmaz, A.M.; Koçtürk, S.; Taga, Y.; Yalçın, A.S. Synergistic Induction of Apoptosis by Quercetin and Curcumin in Chronic Myeloid Leukemia (K562) Cells. Nutr. Cancer 2018, 70, 97-108. [CrossRef]

144. Smith, L.L.; Brown, K.; Carthew, P.; Lim, C.-K.; Martin, E.A.; Styles, J.; White, I.N.H. Chemoprevention of Breast Cancer by Tamoxifen: Risks and Opportunities. Crit. Rev. Toxicol. 2000, 30, 571-594. [CrossRef]

145. Yao, J.; Deng, K.; Huang, J.; Zeng, R.; Zuo, J. Progress in the Understanding of the Mechanism of Tamoxifen Resistance in Breast Cancer. Front. Pharmacol. 2020, 11, 592912. [CrossRef]

146. Huang, J.; Li, H.; Ren, G. Epithelial-mesenchymal transition and drug resistance in breast cancer (Review). Int. J. Oncol. 2015, 47, 840-848. [CrossRef]

147. Nakamura, R.; Ishii, H.; Endo, K.; Hotta, A.; Fujii, E.; Miyazawa, K.; Saitoh, M. Reciprocal expression of Slug and Snail in human oral cancer cells. PLoS ONE 2018, 13, e0199442. [CrossRef]

148. Iqbal, N.; Iqbal, N. Human Epidermal Growth Factor Receptor 2 (HER2) in Cancers: Overexpression and Therapeutic Implications. Mol. Biol. Int. 2014, 2014, 852748. [CrossRef]

149. Li, S.G.; Li, L. Targeted therapy in HER2-positive breast cancer. Biomed. Rep. 2013, 1, 499-505. [CrossRef]

150. Nishimura, R.; Okumura, Y.; Arima, N. Trastuzumab monotherapy versus combination therapy for treating recurrent breast cancer: Time to progression and survival. Breast Cancer 2008, 15, 57-64. [CrossRef]

151. Yamashita, T.; Kawaguchi, H.; Masuda, N.; Kitada, M.; Narui, K.; Hattori, M.; Yoshinami, T.; Matsunami, N.; Yanagihara, K.; Kawasoe, T.; et al. Efficacy of the eribulin, pertuzumab, and trastuzumab combination therapy for human epidermal growth factor receptor 2-positive advanced or metastatic breast cancer: A multicenter, single arm, phase II study (JBCRG-M03 study). Investig. New Drugs 2021, 39, 217-225. [CrossRef]

152. Abu Samaan, T.M.; Samec, M.; Liskova, A.; Kubatka, P.; Büsselberg, D. Paclitaxel's Mechanistic and Clinical Effects on Breast Cancer. Biomolecules 2019, 9, 789. [CrossRef]

153. Chen, W.-C.; Lai, Y.-A.; Lin, Y.-C.; Ma, J.-W.; Huang, L.-F.; Yang, N.-S.; Ho, C.-T.; Kuo, S.-C.; Way, T.-D. Curcumin Suppresses Doxorubicin-Induced Epithelial-Mesenchymal Transition via the Inhibition of TGF- $\beta$ and PI3K/AKT Signaling Pathways in Triple-Negative Breast Cancer Cells. J. Agric. Food Chem. 2013, 61, 11817-11824. [CrossRef]

154. Pardini, B.; Kumar, R.; Naccarati, A.; Novotny, J.; Prasad, R.; Forsti, A.; Hemminki, K.; Vodicka, P.; Bermejo, J.L. 5-Fluorouracilbased chemotherapy for colorectal cancer and MTHFR/MTRR genotypes. Br. J. Clin. Pharmacol. 2010, 72, 162-163. [CrossRef]

155. Ciombor, K.K.; Wu, C.; Goldberg, R.M. Recent Therapeutic Advances in the Treatment of Colorectal Cancer. Annu. Rev. Med. 2015, 66, 83-95. [CrossRef]

156. Findlay, V.; Wang, C.; Watson, D.K.; Camp, E.R. Epithelial-to-mesenchymal transition and the cancer stem cell phenotype: Insights from cancer biology with therapeutic implications for colorectal cancer. Cancer Gene Ther. 2014, 21, 181-187. [CrossRef]

157. Prabhakar, C.N. Epidermal growth factor receptor in non-small cell lung cancer. Transl. Lung Cancer Res. 2015, 4, 110-118. [CrossRef]

158. Lemjabbar-Alaoui, H.; Hassan, O.U.; Yang, Y.-W.; Buchanan, P. Lung cancer: Biology and treatment options. Biochim. Biophys. Acta (BBA) Bioenerg. 2015, 1856, 189-210. [CrossRef]

159. Pienta, K.J.; Smith, D.C. Advances in Prostate Cancer Chemotherapy: A New Era Begins. CA Cancer J. Clin. 2005, 55, 300-318. [CrossRef]

160. Wade, C.A.; Kyprianou, N. Profiling Prostate Cancer Therapeutic Resistance. Int. J. Mol. Sci. 2018, 19, 904. [CrossRef]

161. Nakazawa, M.; Paller, C.; Kyprianou, N. Mechanisms of Therapeutic Resistance in Prostate Cancer. Curr. Oncol. Rep. 2017, 19, 1-12. [CrossRef]

162. Guérin, O.; Fischel, J.L.; Ferrero, J.-M.; Bozec, A.; Milano, G. EGFR Targeting in Hormone-Refractory Prostate Cancer: Current Appraisal and Prospects for Treatment. Pharmaceuticals 2010, 3, 2238-2247. [CrossRef]

163. De Miguel, D.; Lemke, J.; Anel, A.; Walczak, H.; Martinez-Lostao, L. Onto better TRAILs for cancer treatment. Cell Death Differ. 2016, 23, 733-747. [CrossRef]

164. Kong, W.Y.; Yee, Z.Y.; Mai, C.W.; Fang, C.-M.; Abdullah, S.; Ngai, S.C. Zebularine and trichostatin A sensitized human breast adenocarcinoma cells towards tumor necrosis factor-related apoptosis inducing ligand (TRAIL)-induced apoptosis. Heliyon 2019, 5, e02468. [CrossRef]

165. Machlowska, J.; Baj, J.; Sitarz, M.; Maciejewski, R.; Sitarz, R. Gastric Cancer: Epidemiology, Risk Factors, Classification, Ge-nomic Characteristics and Treatment Strategies. Int. J. Mol. Sci. 2020, 21, 4012. [CrossRef] 
166. Pettenati, C.; Ingersoll, M.A. Mechanisms of BCG immunotherapy and its outlook for bladder cancer. Nat. Rev. Urol. 2018, 15, 615-625. [CrossRef]

167. Saghatelyan, T.; Tananyan, A.; Janoyan, N.; Tadevosyan, A.; Petrosyan, H.; Hovhannisyan, A.; Hayrapetyan, L.; Arustamyan, M.; Arnhold, J.; Rotmann, A.-R.; et al. Efficacy and safety of curcumin in combination with paclitaxel in patients with advanced, metastatic breast cancer: A comparative, randomized, double-blind, placebo-controlled clinical trial. Phytomedicine 2020, 70, 153218. [CrossRef]

168. Bayet-Robert, M.; Kwiatkowski, F.; Leheurteur, M.; Gachon, F.; Planchat, E.; Abrial, C.; Mouret-Reynier, M.-A.; Durando, X.; Barthomeuf, C.; Chollet, P. Phase I dose escalation trial of docetaxel plus curcumin in patients with advanced and metastatic breast cancer. Cancer Biol. Ther. 2010, 9, 8-14. [CrossRef]

169. Ghalaut, V.S.; Sangwan, L.; Dahiya, K.; Ghalaut, P.; Dhankhar, R.; Saharan, R. Effect of imatinib therapy with and without turmeric powder on nitric oxide levels in chronic myeloid leukemia. J. Oncol. Pharm. Pract. 2012, 18, 186-190. [CrossRef]

170. Howells, L.M.; Iwuji, C.O.O.; Irving, G.R.B.; Barber, S.; Walter, H.; Sidat, Z.; Griffin-Teall, N.; Singh, R.; Foreman, N.; Patel, S.R.; et al. Curcumin Combined with FOLFOX Chemotherapy Is Safe and Tolerable in Patients with Metastatic Colorectal Cancer in a Randomized Phase IIa Trial. J. Nutr. 2019, 149, 1133-1139. [CrossRef]

171. Epelbaum, R.; Schaffer, M.; Vizel, B.; Badmaev, V.; Bar-Sela, G. Curcumin and Gemcitabine in Patients With Advanced Pan-creatic Cancer. Nutr. Cancer 2010, 62, 1137-1141. [CrossRef]

172. Pastorelli, D.; Fabricio, A.S.C.; Giovanis, P.; D’Ippolito, S.; Fiduccia, P.; Soldà, C.; Buda, A.; Sperti, C.; Bardini, R.; Da Dalt, G.; et al. Phytosome complex of curcumin as complementary therapy of advanced pancreatic cancer improves safety and efficacy of gemcitabine: Results of a prospective phase II trial. Pharmacol. Res. 2018, 132, 72-79. [CrossRef]

173. Kanai, M.; Yoshimura, K.; Asada, M.; Imaizumi, A.; Suzuki, C.; Matsumoto, S.; Nishimura, T.; Mori, Y.; Masui, T.; Kawaguchi, Y.; et al. A phase I/II study of gemcitabine-based chemotherapy plus curcumin for patients with gemcitabine-resistant pancreatic cancer. Cancer Chemother. Pharmacol. 2011, 68, 157-164. [CrossRef]

174. Soldà, C.; Bardini, R.; Sperti, C.; Da Dalt, G.; Gion, M.; Fiduccia, P.; Ursini, F.; Aliberti, C.; Pastorelli, D. Phase II study of Gemcitabine and Curcumin (Meriva ${ }^{\circledR}$ ) as first line treatment for locally advanced or metastatic pancreatic cancer: Preliminary results. Ann. Oncol. 2015, 26, vi102. [CrossRef]

175. Mahammedi, H.; Planchat, E.; Pouget, M.; Durando, X.; Curé, H.; Guy, L.; Van-Praagh, I.; Savareux, L.; Atger, M.; Bayet-Robert, M.; et al. The New Combination Docetaxel, Prednisone and Curcumin in Patients with Castration-Resistant Prostate Cancer: A Pilot Phase II Study. Oncology 2016, 90, 69-78. [CrossRef]

176. Choi, Y.H.; Han, D.H.; Kim, S.-w.; Kim, M.-J.; Sung, H.H.; Jeon, H.G.; Jeong, B.C.; Seo, S.I.; Jeon, S.S.; Lee, H.M.; et al. A randomized, double-blind, placebo-controlled trial to evaluate the role of curcumin in prostate cancer patients with intermittent androgen deprivation. Prostate 2019, 79, 614-621. [CrossRef]

177. Hejazi, J.; Rastmanesh, R.; Taleban, F.-A.; Molana, S.-H.; Hejazi, E.; Ehtejab, G.; Hara, N. Effect of Curcumin Supplementation During Radiotherapy on Oxidative Status of Patients with Prostate Cancer: A Double Blinded, Randomized, Placebo-Controlled Study. Nutr. Cancer 2016, 68, 77-85. [CrossRef]

178. Sanmamed, M.F.; Chester, C.; Melero, I.; Kohrt, H. Defining the optimal murine models to investigate immune checkpoint blockers and their combination with other immunotherapies. Ann. Oncol. 2016, 27, 1190-1198. [CrossRef]

179. Chavez-Dominguez, R.; Perez-Medina, M.; Lopez-Gonzalez, J.S.; Galicia-Velasco, M.; Aguilar-Cazares, D. The Double-Edge Sword of Autophagy in Cancer: From Tumor Suppression to Pro-tumor Activity. Front. Oncol. 2020, 10, 2064. [CrossRef]

180. Mortezaee, K.; Najafi, M. Immune system in cancer radiotherapy: Resistance mechanisms and therapy perspectives. Crit. Rev. Oncol. Hematol. 2021, 157, 103180. [CrossRef]

181. Shakeri, A.; Cicero, A.F.G.; Panahi, Y.; Mohajeri, M.; Sahebkar, A. Curcumin: A naturally occurring autophagy modulator. J. Cell. Physiol. 2019, 234, 5643-5654. [CrossRef]

182. Kantara, C.; Oconnell, M.R.; Sarkar, S.; Moya, S.; Ullrich, R.; Singh, P. Curcumin Promotes Autophagic Survival of a Subset of Colon Cancer Stem Cells, Which Are Ablated by DCLK1-siRNA. Cancer Res. 2014, 74, 2487-2498. [CrossRef]

183. Zhang, J.; Wang, J.; Xu, J.; Lu, Y.; Jiang, J.; Wang, L.; Shen, H.-M.; Xia, D. Curcumin targets the TFEB-lysosome pathway for induction of autophagy. Oncotarget 2016, 7, 75659-75671. [CrossRef] [PubMed]

184. Perrone, L.; Squillaro, T.; Napolitano, F.; Terracciano, C.; Sampaolo, S.; Melone, M.A.B. The Autophagy Signaling Pathway: A Potential Multifunctional Therapeutic Target of Curcumin in Neurological and Neuromuscular Diseases. Nutrients 2019, $11,1881$. [CrossRef] [PubMed]

185. Morón, E.B.; Calderón-Montaño, J.M.; Salvador, J.; Robles, A.; López-Lázaro, M. The dark side of curcumin. Int. J. Cancer 2010, 126, 1771-1775. [CrossRef]

186. Cao, J.; Jia, L.; Zhou, H.-M.; Liu, Y.; Zhong, L.-F. Mitochondrial and Nuclear DNA Damage Induced by Curcumin in Human Hepatoma G2 Cells. Toxicol. Sci. 2006, 91, 476-483. [CrossRef] [PubMed]

187. López-Lázaro, M. Anticancer and carcinogenic properties of curcumin: Considerations for its clinical development as a cancer chemopreventive and chemotherapeutic agent. Mol. Nutr. Food Res. 2008, 52, S103-S127. [CrossRef]

188. Jiao, Y.; Wilkinson, I.J.; Di, X.; Wang, W.; Hatcher, H.; Kock, N.D.; D’Agostino, R., Jr.; Knovich, M.A.; Torti, F.M.; Torti, S.V. Curcumin, a cancer chemopreventive and chemotherapeutic agent, is a biologically active iron chelator. Blood 2009, 113, 462-469. [CrossRef] 
189. Hackman, G.L.; Collins, M.; Lu, X.; Lodi, A.; DiGiovanni, J.; Tiziani, S. Predicting and Quantifying Antagonistic Effects of Natural Compounds Given with Chemotherapeutic Agents: Applications for High-Throughput Screening. Cancers 2020, $12,3714$. [CrossRef]

190. Somasundaram, S.; Edmund, N.A.; Moore, D.T.; Small, G.W.; Shi, Y.Y.; Orlowski, R.Z. Dietary Curcumin Inhibits Chemo-therapyinduced Apoptosis in Models of Human Breast Cancer. Cancer Res. 2002, 62, 3868.

191. Saleh, E.M.; El-awady, R.A.; Eissa, N.A.; Abdel-Rahman, W.M. Antagonism between curcumin and the topoisomerase II inhibitor etoposide: A study of DNA damage, cell cycle regulation and death pathways. Cancer Biol. Ther. 2012, 13, 1058-1071. [CrossRef]

192. Schilsky, R.L. Personalized medicine in oncology: The future is now. Nat. Rev. Drug Discov. 2010, 9, 363-366. [CrossRef]

193. Dugger, S.A.; Platt, A.; Goldstein, D.B. Drug development in the era of precision medicine. Nat. Rev. Drug Discov. 2018, 17, 183-196. [CrossRef]

194. Anand, P.; Kunnumakkara, A.B.; Newman, R.A.; Aggarwal, B.B. Bioavailability of Curcumin: Problems and Promises. Mol. Pharm. 2007, 4, 807-818. [CrossRef]

195. Guo, W.; Song, Y.; Song, W.; Liu, Y.; Liu, Z.; Zhang, D.; Tang, Z.; Bai, O. Co-delivery of Doxorubicin and Curcumin with Polypeptide Nanocarrier for Synergistic Lymphoma Therapy. Sci. Rep. 2020, 10, 1-16. [CrossRef] [PubMed]

196. Chuah, L.H.; Roberts, C.; Billa, N.; Abdullah, S.; Rosli, R.; Manickam, S. Using Nanoparticle Tracking Analysis (NTA) to Decipher Mucoadhesion Propensity of Curcumin-Containing Chitosan Nanoparticles and Curcumin Release. J. Dispers. Sci. Technol. 2014, 35, 1201-1207. [CrossRef]

197. Chuah, L.H.; Billa, N.; Roberts, C.; Burley, J.C.; Manickam, S. Curcumin-containing chitosan nanoparticles as a potential mucoadhesive delivery system to the colon. Pharm. Dev. Technol. 2011, 18, 591-599. [CrossRef]

198. Chuah, L.H.; Roberts, C.J.; Billa, N.; Abdullah, S.; Rosli, R. Cellular uptake and anticancer effects of mucoadhesive curcu-mincontaining chitosan nanoparticles. Colloids Surf. B 2014, 116, 228-236. [CrossRef] 